\title{
Probing the biomolecular (DNA/BSA) interaction by new Pd(II) complex via in-depth experimental and computational perspectives: synthesis, characterization, cytotoxicity, and DFT approach
}

\author{
Mehran Feizi-Dehnayebi ${ }^{1}$ Effat Dehghanian ${ }^{1}$ (D) Hassan Mansouri-Torshizi ${ }^{1}$
}

Received: 8 November 2021 / Accepted: 2 February 2022 / Published online: 25 February 2022

(C) Iranian Chemical Society 2022

\begin{abstract}
Scientists should not forget that the rate of death as a result of cancer is far more than that of other diseases like influenza or coronavirus (COVID-19), so the research in this field is of cardinal significance. Therefore, a new and hydrophilic palladium(II) complex of the general formula $\left[\mathrm{Pd}(\mathrm{bpy})(\right.$ proli-dtc) $] \mathrm{NO}_{3}$, in which bpy and proli-dtc are 2,2'-bipyridine and pyrroline dithiocarbamate ligands, respectively, was synthesized and characterized utilizing spectral and analytical procedures. Density functional theory (DFT) calculation was also performed with B3LYP method in the gas phase. The DFT and spectral analysis specified that the Pd(II) atom is found in a square-planar geometry. HOMO/LUMO analysis, quantum chemical parameters and MEP surface of the complex were investigated to acquire an intuition about the nature of the compound. Partition coefficient and water solubility determination showed that both lipophilicity and hydrophilicity of the compound are more than cisplatin. The $50 \%$ inhibition concentration $\left(\mathrm{IC}_{50}\right)$ value was evaluated against $\mathrm{K} 562$ cancer cells, the obtained result has revealed a promising cytotoxic effect. DNA and BSA binding of the complex were explored through multi-spectroscopic (UV-Vis, fluorescence, FRET, and CD) and non-spectroscopic (gel electrophoresis, viscosity and docking simulation) techniques. The obtained findings demonstrated that the complex strongly interacts with CT-DNA by hydrophobic interactions and possesses medium interaction with BSA via hydrogen bond and van der Waals forces, thus BSA could efficiently carry out complex transportation. Furthermore, the results of docking simulation agree well with the experimental findings. In conclusion, the new Pd(II) complex has cytotoxic activity and could interact with DNA and BSA effectively.
\end{abstract}

Effat Dehghanian

dehghanian@chem.usb.ac.ir

Mehran Feizi-Dehnayebi

m.feizi@ sutech.ac.ir

Hassan Mansouri-Torshizi

hmtorshizi@hamoon.usb.ac.ir

1 Department of Chemistry, University of Sistan

and Baluchestan, Zahedan, Iran 


\section{Graphical abstract}

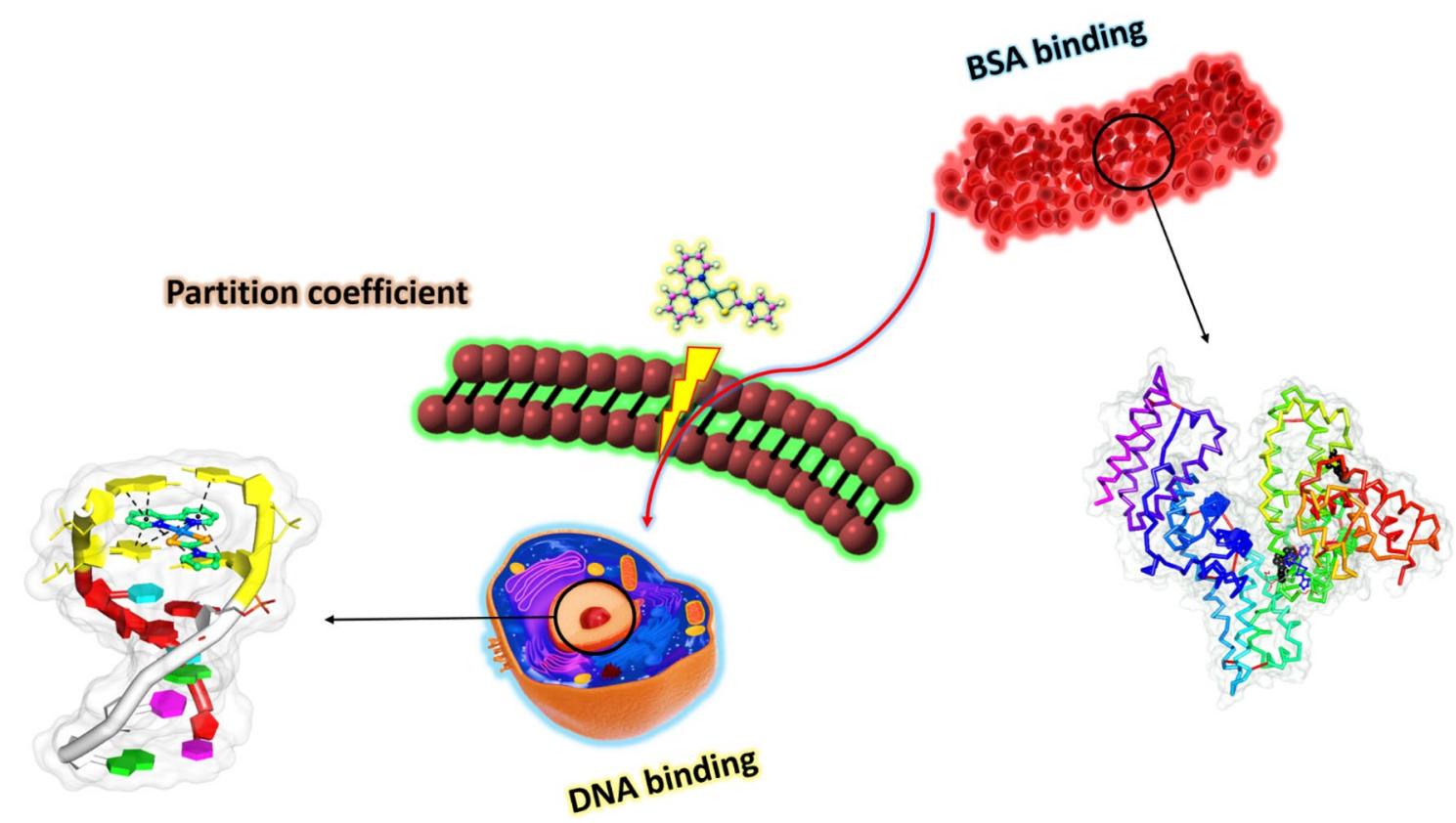

Keywords Pd(II) complex $\cdot$ HOMO/LUMO analysis $\cdot$ Cytotoxicity $\cdot$ Spectroscopic $\cdot$ Docking simulation

\section{Introduction}

Cancer is one of the main issues in the health care in terms of fatality and therapy costs [1]. Although many drugs have been offered to the market, but the cancer mortality rate has remained constant over the last few decades. Among these drugs are platinum complex anticancer drugs including cisplatin, carboplatin, and oxaliplatin that have some side effects and intrinsic and acquired resistance [2, 3]. So, there is an urgent demand for developing more efficient drugs from the laboratory test to the clinical usage. Therefore, the main aim of most researches in bioinorganic chemistry groups is to discover more effective anticancer complexes that can reduce the side effects and be utilized for the chemotherapy.

The idea of substituting central metal ion of platinumbased anticancer drugs has begun with $\mathrm{Au}(\mathrm{III}), \mathrm{Rh}(\mathrm{I}), \operatorname{Ir}(\mathrm{I})$, and in particular $\mathrm{Pd}(\mathrm{II})$. Both $\mathrm{Pt}(\mathrm{II})$ and $\mathrm{Pd}(\mathrm{II})$ follow the orbital hybridization of $\mathrm{dsp}^{2}$ and create square planar metal complexes [4]. On the other hand, palladium complexes are more beneficial in the treatment of most tumors, which are resistant to cisplatin [5] because the rate of hydration is on average $10^{3}$ times faster than platinum analogous [6]. Therefore, the pharmaceutical activity of palladium complexes has been considered as potent antitumor compounds. In this regard, some palladium(II) complexes have shown desirable results for biological response $[7,8]$.
There are six types of bipyridines, which have nitrogen atoms at different locations on the rings. They are also known as bipyridyls and dipyridyls. Several bipyridines exist naturally where 2,2'-bipyridine is present in crude oil [9]. 2,2'-bipyridine belongs to a class of bipyridines and was first prepared in 1888 by dry distillation of copper salt of picolinic acid [10]. It has been reported that 2,2'-bipyridine exists in the lowest triplet state in both cisoid and transoid conformations $[11,12]$. Studies have shown that 2,2'-bipyridine is a symmetric and planar molecule with the bond length between two pyridine rings of about $1.50 \AA[13,14]$. Dithiocarbamates are metal-chelating ligands that have been used for treating some diseases such as fungi, AIDS and bacteria [15, 16]. Pyrrolidine dithiocarbamate is an antioxidant agent that has been used for the treatment of metal intoxication, atherosclerosis and inflammation [17]. It has been also shown that some transition metal complexes of pyrrolidine dithiocarbamate are highly cytotoxic due to the induction of tumor cell apoptosis [16, 18]. Moreover, some studies reported a reduction in renal damages when diethyldithiocarbamate have been administered along with cisplatin [19, 20].

Probing the binding affinity between transition metal complexes and deoxyribonucleic acid (DNA) is a modern era of science because it is a vital stage for the rational design of the new compounds with anticancer activity [21]. Metal complexes bind non-covalently to DNA via 
electrostatic attraction, hydrophobic interactions, and hydrogen bonds in the groove zone of DNA. Some of them intercalate with the DNA base pairs and construct a $\pi-\pi$ interaction which is called intercalative mode [22]. This interaction mode generally affects the DNA conventional activity and causes the transition metal complexes to have a variety of broad applications in bioinorganic chemistry [23].

Serum albumin (SA) is one of the significant compounds that influence the concentration of free drug, its side effects, and half-life in the blood circulation system. SA that is a primitive extracellular protein, forms $60 \%$ of whole blood plasma and acts as a carrier conjugate and storage macromolecule for the large range of bio-active drug compounds [24]. Human serum albumin (HSA) and bovine serum albumin (BSA) are the most specifically exploited SA that have been applied for the targeted delivery of diverse metallo drugs [24]. BSA is utilized as a desired model protein for HSA in medical sciences due to their conformation and sequence resemblance [25]. BSA, a heart-shaped protein, is made of 583 amino acid residues with around $60 \% \alpha$ - helix and 17 disulfide bridges [26]. The amino acid residues of BSA are classified into the following domains: domain I (residues 1-195), domain II (residues 196-383), and domain III (residues 384-583) where each domain is split into two sub-domains, A and B [27]. Therefore, there are three binding sites for drug compounds on the BSA macromolecule (domains I, II, and III) [28]. A thorough study about the interaction of palladium complex categories to DNA and BSA can supply beneficial information for developing new Pd-based biologically active complexes.

The proposal of this paper has been distributed among the above paragraphs. We have prepared and fully characterized a mononuclear Pd(II) complex of 2,2'-bipyridine and pyrroline dithiocarbamate ligands using spectroscopic procedures (FT-IR, ${ }^{1} \mathrm{H}$ NMR and UV-Vis), elemental analyses, conductivity measurement, as well as density functional theory (DFT) approach. We have also checked the lipophilicity and cytotoxicity of metal complexes in comparison to cisplatin. The binding behavior of the compound with both biomolecules, i.e. calf - thymus DNA (CT-DNA) and BSA, under physiological conditions has also been studied utilizing a variety of experimental techniques including fluorescence emission spectroscopy, UV-Vis spectrophotometry, gel electrophoresis assay, circular dichroism (CD) spectroscopy, fluorescence resonance energy transfer (FRET) calculation, and viscosity measurements. Furthermore, the molecular docking simulation was conducted to inquire about the interaction of the $\operatorname{Pd}(\mathrm{II})$ complex with biomolecules.

\section{Experimental}

\section{Materials and general techniques}

CT-DNA (type-1, highly polymerized), ethidium bromide (EB), palladium(II) chloride $\left(\mathrm{PdCl}_{2}\right)$, and Tris- $\mathrm{HCl}$ buffer were bought from Aldrich company (USA) and utilized with no purification. Commercial grade potassium Chloride $(\mathrm{KCl})$, carbon disulfide $\left(\mathrm{CS}_{2}\right)$, bpy (2,2'-bipyridine), proli (pyrroline), sodium hydroxide $(\mathrm{NaOH})$, and octanol were obtained from Merck chemical company. Analytical grade solvents like methanol, acetonitrile and commercial acetone were bought from Merck. Double distilled water was utilized all over the experiments. $\left[\mathrm{Pd}(\mathrm{bpy}) \mathrm{Br}_{2}\right]$ was prepared by a procedure similar to that reported in the paper [29]. BSA (66.463 kDa molecular weight) was purchased from Sigma.

Infrared spectra of the prepared $\mathrm{Pd}(\mathrm{II})$ complex and ligands (potassium bromide disks, $400-4000 \mathrm{~cm}^{-1}$ ) were recorded on a Shimadzu-460 spectrometer. Emission intensity measurements were performed by a Varian Cary Eclipse spectrophotometer. ${ }^{1} \mathrm{H}$ NMR spectra were measured on a Bruker FT-NMR spectrometer (Ac model) utilizing TMS (tetramethylsilane, 0-12 ppm) as an internal reference at $400 \mathrm{MHz}$. Lipophilicity of the complex was determined using partition coefficient test through shakeflask procedure. Ostwald micro-viscometer (Schott-geräte model) was used to evaluate viscosity of all samples at $27{ }^{\circ} \mathrm{C}$. A JASCO-V570 UV-Vis spectrophotometer was applied to measure the electronic absorption spectra. Molar conductivity was conducted on a F200 (WTW) digital conductometer, using deionized water. A Heraus CHNO-RAPID elemental analyzer was used to perform the CHN analysis. CD spectra of BSA and interacted BSA were measured on Aviv CD spectrometer (USA, 215 model) using $1 \mathrm{~mm}$ quartz cell. Melting point of the ligand and decomposition temperature of the complex were evaluated on an Electrothermal-9100 apparatus and are uncorrected. Using Maxi HD $15 \times 15$ Tank, Ladder 100 bp, gel electrophoresis mobility experiment was carried out on CCD-5 Gel Doc.

\section{Preparation of the ligand and corresponding Pd(II) complex}

\section{Synthesis of proli-dtc-K}

Potassium salt of pyrroline dithiocarbamate (Fig. 1) was made in our laboratory resembling to that of pyrrolidine dithiocarbamate sodium salt [30]: Potassium hydroxide ( $0.5 \mathrm{~mol}, 2.8 \mathrm{~g}$ in $30 \mathrm{~mL}$ water) was added to pyrroline 

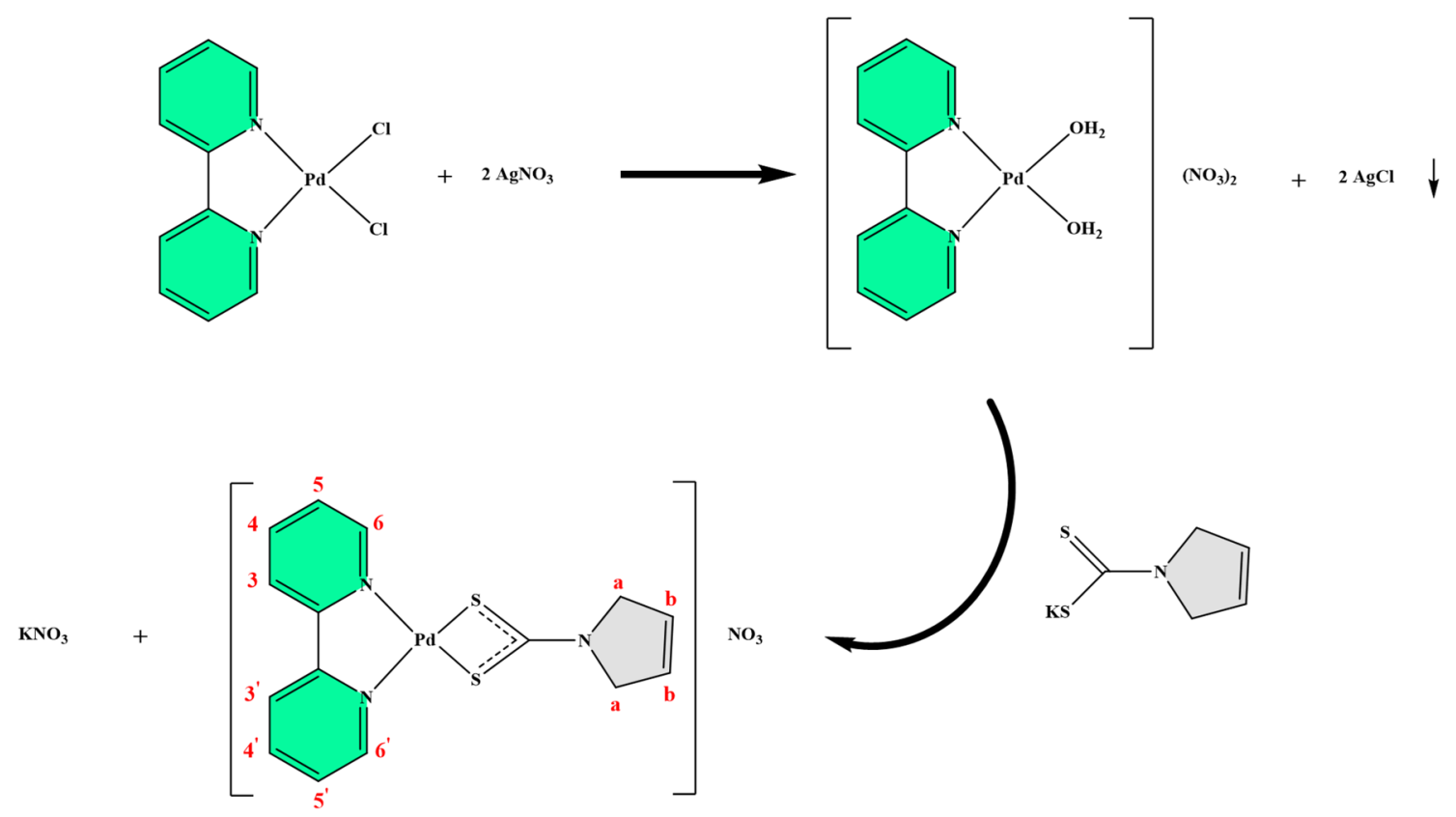

Fig. 1 Synthetic reaction pathway and ${ }^{1} \mathrm{H}-\mathrm{NMR}$ numbering scheme of $\left[\mathrm{Pd}(\mathrm{bpy})(\right.$ proli-dtc) $] \mathrm{NO}_{3}$

(0.5 mol, $3.83 \mathrm{~mL}$ in $30 \mathrm{~mL}$ acetone) precooled in an ice bath. Then, $10 \mathrm{~mL}$ of $\mathrm{CS}_{2}$ was added slowly and stirred in a closed flask for $4 \mathrm{~h}$ at $0{ }^{\circ} \mathrm{C}$ and $4 \mathrm{~h}$ at room temperature and filtered. The filtrate was evaporated under reduced pressure at $40{ }^{\circ} \mathrm{C}$. The crude residue was crystallized by dissolving in $10 \mathrm{~mL}$ water and subsequently filtered. Diffusing acetone into the filtrate for 4 days gave needle-shaped microcrystals. These crystals were filtered and suspended in $30 \mathrm{~mL}$ acetone, and then, filtered again. The pure product which was dried in an oven at $35-40{ }^{\circ} \mathrm{C}$ yielded $8.10 \mathrm{~g}(88.5 \%)$. The pail yellowish microcrystals, m. p. $140-143{ }^{\circ} \mathrm{C} .{ }^{1} \mathrm{H}$ NMR (400 MHz, DMSO-d 6 , sb: singlet broad) $\delta(\mathrm{ppm})$ : 1.69-1.99 ( $\mathrm{sb}, 2 \mathrm{H}, \mathrm{b}$ protons $)$, 3.49-3.70 (sb, 4H, a protons) (Fig. 1). Anal. Calcd. for $\mathrm{C}_{5} \mathrm{H}_{6} \mathrm{NS}_{2} \mathrm{~K}$ (183): C, 32.79; H, 3.28; N, 7.65\%. Founded: $\mathrm{C}, 32.71 ; \mathrm{H}, 3.27$; N, $7.69 \%$. IR (KBr) the three characteristic stretching bands at 1422, 998 and $632 \mathrm{~cm}^{-1}$ assigned to $v(\mathrm{~N}-\mathrm{CSS}), \mathrm{v}(\mathrm{CSS})_{\mathrm{as}}$ and $v(\mathrm{CSS})_{\mathrm{s}}$ modes, respectively [31].

\section{Synthesis of $\left[\mathrm{Pd}(\mathrm{bpy})(\right.$ proli-dtc) $] \mathrm{NO}_{3}$}

\section{2,2'-bipyridinepyrrolinedithiocarbamatopalladium(II) nitrate, $\mathrm{C}_{15} \mathrm{H}_{14} \mathrm{~N}_{4} \mathrm{O}_{3} \mathrm{~S}_{2} P d$, M. Wt. $468 \mathrm{~g} / \mathrm{mol}$}

This complex was made by reaction of $\left[\mathrm{Pd}(\mathrm{bpy})\left(\mathrm{H}_{2} \mathrm{O}\right)_{2}\right]$ $\left(\mathrm{NO}_{3}\right)_{2}$ and sodium salt of pyrroline dithiocarbamate. Thus, $0.5 \mathrm{~g}(1.5 \mathrm{mmol})$ of $\left[\mathrm{Pd}(\mathrm{bpy}) \mathrm{Cl}_{2}\right]$ was suspended in $80 \mathrm{~mL}$ water-acetone mixture $\left(1: 3_{\mathrm{V} / \mathrm{V}}\right)$, and then, $0.51 \mathrm{~g}(3 \mathrm{mmol})$ of $\mathrm{AgNO}_{3}$ was added. The reaction blend was stirred and heated in dark under reflux for $7 \mathrm{~h}$ at $58^{\circ} \mathrm{C}$. Stirring continued at room temperature for another $11 \mathrm{~h}$. The $\mathrm{AgCl}$ precipitate so formed was filtered off by Wattman filter paper 41 and then 42 . To the filtrate, $0.26 \mathrm{~g}$ ( $1.5 \mathrm{mmol})$ of proli-dtcK predissolved in $10 \mathrm{~mL}$ water was added dropwise under continuous stirring. At this stage yellow precipitate appeared. Stirring and heating at $55^{\circ} \mathrm{C}$ continued until the solvent fully evaporated. The yellow residue was dried in an oven at $40-50{ }^{\circ} \mathrm{C}$ for a period of $48 \mathrm{~h}$. The residue was dissolved at $60{ }^{\circ} \mathrm{C}$ in $80 \mathrm{~mL}$ methanol-acetonitrile mixture $\left(1: 1_{\mathrm{V} / \mathrm{V}}\right)$ and filtrated. The clear yellowish-orange filtrate was evaporated to $20 \mathrm{~mL}$ at $35^{\circ} \mathrm{C}$. The needle-shaped microcrystals so formed was filtrated and washed with acetone and dried in an oven at $40{ }^{\circ} \mathrm{C}$ for $48 \mathrm{~h}$. Yield was $0.36 \mathrm{~g}(65 \%)$ and decomposed at $272-278{ }^{\circ} \mathrm{C}$. (found: C, 38.49; H, 3.01; N, 12.00. Calc for $\mathrm{PdC}_{15} \mathrm{H}_{14} \mathrm{~N}_{4} \mathrm{O}_{3} \mathrm{~S}_{2}(\mathrm{Fw}=468)$ : C, 38.46; $\mathrm{H}$, $2.99 ; \mathrm{N}, 11.97 \%)$. IR $(\mathrm{KBr})\left(\mathrm{cm}^{-1}\right)$ : the three distinguishing stretching bands: $v$ (N-CSS) 1538, $v(\mathrm{CSS})_{\mathrm{as}} 851, v(\mathrm{CSS})$ $713 \mathrm{~cm}^{-1}$ [32]. Uncoordinated and sharp $v\left(\mathrm{NO}_{3}{ }^{-}\right) 1375$ [33]. ${ }^{1} \mathrm{H}$ NMR (400 MHz, DMSO-d 6 , sb, singlet broad) $\delta$ (ppm): 2.05 (2H, b protons), $3.65(4 \mathrm{H}$, a protons $), 7.70(2 \mathrm{H}$, $\left.\mathrm{H}_{5} / \mathrm{H}_{5^{\prime}}\right), 8.15\left(2 \mathrm{H}, \mathrm{H}_{3} / \mathrm{H}_{3^{\prime}}\right), 8.35\left(2 \mathrm{H}, \mathrm{H}_{4} / \mathrm{H}_{4^{\prime}}\right)$ and $8.61(2 \mathrm{H}$, $\mathrm{H}_{6} / \mathrm{H}_{6}$ ) [34]. In the ${ }^{1} \mathrm{H} \mathrm{NMR}$ of [Pd(bpy)(proli-dtc)] $\mathrm{NO}_{3}$, the protons of non - deutrated DMSO present in DMSO - d6 as solvent, appeared at $2.03 \mathrm{ppm}$ indicating that the DMSO is not present in the coordination sphere. Because reports [35] showed that the coordinated DMSO to palladium resonate at 3.43 ppm, i.e. $~ 1 \mathrm{ppm}$ downfield relative to the free DMSO (2.53 ppm in the complex). UV-Vis spectra demonstrate 
four bands at 313 ( $\log \varepsilon=1.43), 305$ (1.45), 248 (3.84) and 202 (2.92) may be assigned to intraligand $\pi \rightarrow \pi^{*}$ and $n \rightarrow \pi^{*}$ transition of $\mathrm{CSS}^{-}$group and 2,2-bipyridine ligand. Molar conductivity $123 \mathrm{~cm}^{2} \mathrm{ohm}^{-1} \mathrm{~mol}^{-1}$ illustrating $1: 1$ electrolyte [36]. Figure 1 shows the proposed reaction pathway for the above procedure followed by characterization data.

\section{DFT calculation}

The molecular structure of complex and ligands was built using GaussView05 software. Full geometry optimization of them was conducted in the gas phase using B3LYP method via Gaussian09W package [37]. 6-311G(d,p) basis set was used to describe hydrogen, carbon, nitrogen, and sulfur atoms and aug-cc-pVTZ-pp for palladium atom [38, 39]. Then, to ensure the stability of the complex and its ligands, the harmonic vibrational frequency calculations were conducted at the same level of calculation. No imaginary frequency was found for the ground state, which confirms that all structures are in true minima. Furthermore, frequency output files were used for the electronic structure calculations. Frontier molecular orbital (FMO) analysis of the $\mathrm{Pd}(\mathrm{II})$ complex and corresponding ligands was performed and the energy difference $\Delta \mathrm{E}\left(\mathrm{E}_{\mathrm{LUMO}}-\mathrm{E}_{\mathrm{HOMO}}\right)$ was utilized to detect global reactivity parameters. Furthermore, Molecular electrostatic potential (MEP) surface was also provided and analyzed for the complex.

\section{Stability evaluation}

In an aqueous solution, the stability of any compound may be evaluated by recording its electronic absorption spectra at different time intervals. Solution of the prepared [Pd(bpy) (proli-dtc) $\mathrm{NO}_{3}$ complex in Tris-HCl buffer or double-distilled water was incubated for $0-20 \mathrm{~h}$ at $37{ }^{\circ} \mathrm{C}$.

\section{Lipophilicity determination}

Lipophilicity of the Pd(II) complex was assessed via flaskshaking procedure via n-octanol/doubly distilled water phase partitions [40]. A blend of n-octanol-water $(10 \mathrm{~mL})$ with equal volume and a small amount of [Pd(bpy)(proli-dtc)] $\mathrm{NO}_{3}$ complex $(0.001 \mathrm{~g} / 10 \mathrm{~mL})$ was shaken continuously for overnight, and then, left aside. At the equilibrium condition, n-octanol layer was separated carefully from the water layer for palladium(II) complex analysis. The concentration of this metal complex in each separated layer was evaluated from electronic absorption spectroscopy and utilized for the calculation of $\log \mathrm{P}$ (partition coefficient) according to the following Eq. (1): $\log P=\log \left(\frac{[\text { complex }]_{\text {octanolphase }}}{[\text { complex }]_{\text {waterphase }}}\right)$

\section{Cytotoxicity assay}

Antiproliferative behavior of the metal complex was determined using K562, chronic myelogenous Leukemia Cell Line (cell bank of Pasteur Institute of Iran). The cells were grown in RPMI (Roswell Park Memorial Institute, 1640 medium) supplemented with streptomycin and penicillin $(5 \mu \mathrm{g} / \mathrm{mL})$, L-glutamine $(2 \mathrm{mM})$ and $10 \%(\mathrm{v} / \mathrm{v})$ heat-inactivated fetal calf serum at $37{ }^{\circ} \mathrm{C}$ under a highly humidified atmosphere of a 5\% carbon dioxide and 95\% air. The growth inhibition of K562 via metal complex was evaluated utilizing MTT (3-(4,5-dymethylthiazol-yl)-2,5-diphenyltetrazolium bromide) experiment [41]. It is based on the conversion of soluble yellowish MTT to insoluble purple formazan through living cells. Different Pd(II) complex concentrations $(0-70 \mu \mathrm{M})$ were added to the harvested cells and incubated for $24 \mathrm{~h}$. Thereafter, $25 \mu \mathrm{L}$ of MTT solution $(5 \mathrm{mg} / \mathrm{mL}$ in phosphate-buffered saline (PBS)) was added to each well having fresh and cultured medium at the last $4 \mathrm{~h}$. The produced formazan precipitate was dissolved in a solution of $50 \%$ dimethylformamide (DMF) and 10\% sodium dodecyl sulfate (SDS) and left at $37{ }^{\circ} \mathrm{C}$ in dark for $2 \mathrm{~h}$ and then the optical density (OD) was read using spectrophotometer ELISA reader, Australia, at $570 \mathrm{~nm}$ with multi-well scanning. Finally, $50 \%$ inhibition concentration $\left(\mathrm{IC}_{50}\right)$ of the metal complex was measured from the diagram of $\%$ cell viability against the metal complex concentration that was added to the growth medium [42].

\section{Sample preparation for evaluation of macromolecules interaction}

Stock solutions of both biomolecules, i.e. CT-DNA $(1.5 \mathrm{mg} /$ $\mathrm{mL})$ and $\mathrm{BSA}(3 \mathrm{mg} / \mathrm{mL})$ were prepared in Tris- $\mathrm{HCl}$ buffer, $\mathrm{pH}=7.2$, followed by stirring till homogenous solutions were obtained. Then, the stocked solutions were stored at $277 \mathrm{~K}$ for further experimental usage for no more than ten days. The CT-DNA mother solution showed a ratio of electronic absorbance at 260 to that of $280 \mathrm{~nm}\left(\mathrm{~A}_{260} /\right.$ $\mathrm{A}_{280}$ ) between 1.8 and 1.9, representing that the CT-DNA was without any protein contamination. The UV absorbance was used to predict BSA and CT-DNA concentration per nucleotide at 280 and $260 \mathrm{~nm}$, respectively using $\varepsilon=44,300 \mathrm{M}^{-1} \mathrm{~cm}^{-1}$ for BSA and $\varepsilon=6600 \mathrm{M}^{-1} \mathrm{~cm}^{-1}$ for DNA [43, 44]. The complex stock solution was obtained via dissolving the complex in Tris- $\mathrm{HCl}$ buffer to get the concentration of $10^{-4} \mathrm{M}$. 


\section{Electronic absorption method}

Electronic absorption measurement is a simple and efficient procedure in studying the interaction of small molecules toward large biomolecules. To study the binding affinity of Pd(II) complex with DNA and BSA, two assays were accomplished. In the first one, CT-DNA and BSA solutions were made separately through the addition of Tris-HCl buffer to the mother solution of CT-DNA (25 $\mu \mathrm{L})$ and BSA $(450 \mu \mathrm{L})$ to obtain the final volume of $1.5 \mathrm{~mL}$. In order to perform the titration process, between 20 and 300 and $300-1400 \mu \mathrm{L}$ of title complex $\left(10^{-4} \mu \mathrm{M}\right)$ was added to the CT-DNA and BSA, respectively. To reach equilibrium, the solution of DNA/BSA-Pd(II) complex was stirred and retained 3 min prior to each absorption measurement. Titration was followed until the absorbance intensity was constant by the addition of metal complex. Now, the results can be analyzed through the following equation [45]:

$$
\frac{1}{\left(A-A_{0}\right)}=\frac{1}{\left(A_{\infty}-A_{0}\right)}+\frac{1}{K_{a p p}\left(A_{\infty}-A_{0}\right)} \cdot \frac{1}{[\text { complex }]}
$$

where $A$ and $A_{0}$ are the absorption of interacted and noninteracted biomolecules (CT-DNA or BSA) with Pd(II) complex at 260 and $280 \mathrm{~nm}$, respectively. $A_{\infty}$ is the final absorbance of CT-DNA at $260 \mathrm{~nm}$ or BSA at $280 \mathrm{~nm}$ in which by addition of $\mathrm{Pd}(\mathrm{II})$ complex no absorption enhancement was seen. $K_{a p p}$ and [complex] are the binding constant and complex concentration, respectively. The diagram of $\frac{1}{A-A_{0}}$ against $\frac{1}{\text { [complex] }}$ gives the value of $K_{a p p}$ via division of its intercept to the slope.

In the second assay, CT-DNA and BSA denaturation via metal complex was investigated through the evaluation of the midpoint transition $\left(\mathrm{L}_{1 / 2}\right) .1 .5 \mathrm{~mL}$ of CT-DNA $(25 \mu \mathrm{L}$ stock solution $+1.475 \mathrm{~mL}$ Tris-HCl buffer) or BSA (450 $\mu \mathrm{L}$ stock solution $+1.05 \mathrm{~mL}$ Tris- $\mathrm{HCl}$ buffer) was poured into the sample cell and the same amount of Tris- $\mathrm{HCl}$ buffer was poured into the reference cell. Then, 20, 30, 45, $60,80,100, \ldots \ldots .300 \mu \mathrm{L}$ (for DNA) and $300,400,500$, ...0.1400 $\mu \mathrm{L}$ (for BSA) of the Pd(II) stock solution was added to both cells. The reason that metal solution was added to the reference cell is to remove the Pd(II) complex absorption from the final spectra. After each addition, 3 min for incubation was considered and then the absorbance was recorded at $\lambda=640 \mathrm{~nm}$ for all, at $\lambda=280$ for BSA and $\lambda=260$ for DNA solutions. Then, the absorbances at $640 \mathrm{~nm}\left(\mathrm{~A}_{640}\right)$ were subtracted from the absorbances recorded at $280 \mathrm{~nm}$ for BSA $\left(\mathrm{A}_{280}\right)$ and $260 \mathrm{~nm}$ for CT-DNA $\left(\mathrm{A}_{260}\right)$ and the results $\left(\mathrm{A}_{280}-\mathrm{A}_{640}\right.$ for BSA and $A_{260}-A_{640}$ for DNA) were plotted against the total complex concentration at each step of titration.

\section{Fluorescence spectroscopic method}

Emission titration experiments were measured for DNA interaction in the range of $540-740 \mathrm{~nm}$ and for BSA interaction from 310 to $480 \mathrm{~nm}$, using a fluorescence cuvette with the path length of $1 \mathrm{~cm}$. The $\left[\mathrm{Pd}(\mathrm{bpy})(\right.$ proli-dtc) $] \mathrm{NO}_{3}$ complex has no substantial fluorescence emission rate in any of the above ranges. Therefore, DNA and BSA interaction experiments are not impaired in the interaction with this complex. Both DNA and BSA binding were carried out at three temperatures of 293, 300 and 310. For each experiment, apparatus parameters, i.e. the slits width (excitation and emission at 5 and $10 \mathrm{~nm}$, respectively) and excitation voltage (at $80 \mathrm{~V}$ ), were kept fixed. In DNA binding titration, a solution containing CT-DNA ( $90 \mu \mathrm{L}$ from stock solution) and EB ( $20 \mu \mathrm{L}$ from stock solution of $0.023 \mathrm{mg} / \mathrm{mL})$ was mixed with $0.87 \mathrm{~mL}$ of Tris- $\mathrm{HCl}$ buffer to achieve the final volume of $0.98 \mathrm{~mL}$ and titrated with various volumes of the metal complex (i.e. $40,55,70, \ldots, 180 \mu \mathrm{L}$ ). The resulted $\mathrm{EB}+\mathrm{CT}$-DNA blend is much fluorescence active at $\sim 600 \mathrm{~nm}$ compared to the free EB solution due to insertion of EB in the intercalation sites of CT-DNA [46]. In the BSA binding titration, $60 \mu \mathrm{L}$ of BSA stock solution was added to $0.94 \mathrm{~mL}$ of Tris- $\mathrm{HCl}$ buffer to attain the final volume of $1 \mathrm{~mL}$ and titrated with $10,20,25, \ldots$ and $125 \mu \mathrm{L}$ of the metal complex. Each EB + CT-DNA- and BSA-metal complex sample solutions were excited at 540 and $295 \mathrm{~nm}$ and the corresponding emissions at 604 and $345 \mathrm{~nm}$ were observed, respectively. Prior to recording each spectrum during titration, the solution was remained for $3 \mathrm{~min}$ in the cell to reach equilibrium at the corresponding temperature. In order to analysis the fluorescence spectra, all patterns were overlaid.

\section{FRET calculation}

FRET calculation can be applied as an important procedure to quantify the critical distance from donor to acceptor compounds, in which the binding affinity between the two is an indicator of this. "Energy transfer calculation section" will include further detail on this method.

\section{Gel electrophoresis assay}

Gel electrophoresis experiment was conducted to observe the binding property of a newly made metal complex with CT-DNA. Since the backbone charge of DNA is negative, so in the presence of an electric field, DNA segments are conducted to the positively charged electrode [47]. The movement speed of DNA is proportional to its mass and size in the absence and presence of various concentrations of attached compounds. EB (fluorescent dye) that intercalates within the bases of nucleic acids was used to follow DNA in the gel. To perform the experiment, $30 \mu \mathrm{L}$ of 
CT-DNA was poured into a container with no metal complex added. The same amount of CT-DNA was placed in another three containers and 10,15 and $20 \mu \mathrm{L}$ of complex solution $\left(7 \times 10^{-4} \mathrm{M}\right)$ was added to each. Then, the total volume of all four vessels was reached to $60 \mu \mathrm{L}$ utilizing Tris- $\mathrm{HCl}$ buffer. The containers were blended and incubated at $37^{\circ} \mathrm{C}$ for one hour. Bromophenol blue dye was added to each sample and electrophoresis was performed on 3\% agarose gel containing EB and TAE buffer for $60 \mathrm{~min}$ at $70 \mathrm{~V}$. The UV light was utilized in order to visualize the bands through CCD-5 Gel Doc System, and photographs were taken.

\section{Viscosity (hydrodynamic) measurements}

To further explain the binding mode between metal complex and DNA, viscometric measurements were applied utilizing an Ostwald micro-viscometer, Germany, at $27^{\circ} \mathrm{C}$. The fluidity times of all solutions in Tris- $\mathrm{HCl}$ buffer were recorded 4 times through a digital stopwatch, and then, an average was utilized for calculations. The classical intercalator, EB, was utilized as a control. Through the viscosity experiments, the molar concentrations of $\mathrm{Pd}(\mathrm{II})$ complex and EB were varied $(0-24 \mu \mathrm{M})$ while the CT-DNA concentration has been kept unchanged $(0.1 \mathrm{mM})$ to attain the binding ratio of $\mathrm{R}$ ( $\mathrm{R}=[\mathrm{Pd}(\mathrm{II})$ complex $] /[\mathrm{CT}$-DNA]) equals to $0.00,0.05,0.10$, $0.15,0.20,0.25,0.30,0.35,0.40$. The relative viscosity of CT-DNA solution with $(\eta)$ and without $\left(\eta_{0}\right)$ of the mentioned complex was estimated utilizing the formula $\eta=\left(t-t_{0}\right) / t_{0}$, where $t$ and $t_{0}$ are recorded fluidity time of CT-DNA solution and buffer in seconds, respectively. The alteration in the viscosity was plotted as $\left(\eta / \eta_{0}\right)^{1 / 3}$ against $\mathrm{R}$.

\section{Circular dichroism (CD) spectroscopy}

In order to clarify the conformational alteration in the BSA secondary structure produced via $\mathrm{Pd}(\mathrm{II})$ complex interaction, the CD spectra of various BSA:Pd(II) complex molar ratios (1:0, 1:6 and 1:8) samples were recorded from 200 to $260 \mathrm{~nm}$ at $298 \mathrm{~K}$, utilizing CD spectrometer-AVIV (model 215) with a $1 \mathrm{~mm}$ quartz cell. BSA total concentration in each sample was maintained fix $(5.5 \mu \mathrm{M}$ in working Tris- $\mathrm{HCl}$ buffer) and the concentration of prepared complex varied ( 33 and $44 \mu \mathrm{M}$ ). All CD data were obtained by subtracting the baseline, i.e. Tris-HCl buffer spectrum from all measurements and converted to the molar ellipticity (deg. $\mathrm{cm}^{2}$.d.mol ${ }^{-1}$ ) and then smoothed. To evaluate the secondary structural elements, the CDNN program was utilized [48].

\section{Docking simulation}

Molecular docking simulation was conducted in order to evaluate the binding free energy $\left(\Delta G^{0}\right)$ and predict the underlying interaction of newly metal complex with DNA and protein by Auto Dock Tools 1.5.6 and Auto Dock 4.2 packages. The optimized structure of the metal complex was changed to PDB format via GaussView 5.0 [49] and used for docking procedure. The crystal structure of DNA (ID: 198D) and BSA (ID: 4OR0) with $1.97 \AA$ and $2.58 \AA$ resolutions, respectively, were downloaded from the site of https://www.rcsb.org./pdb (related to the protein data bank) and initially prepared through eliminating extra compounds like water, other ligands, and additional monomers if there were any. Before the simulation, polar hydrogens along with Kollman partial atomic charge were added to the PDB file of biomolecules and Gasteiger partial atomic charge was assigned for the structure of complex with the help of Autodock tools. After creating the PDBQT files of all structures, they were utilized for defining grid boxes. Docking was performed for DNA and BSA using Auto Grid program via setting the grid size to $62 \times 50 \times 50$ (for DNA blind docking) and $58 \times 60 \times 50$ (for both BSA drug binding sites I and II) points in the X-, Y- and Z- axis and spacing of $0.375 \AA$ having a grid center of $x=28.429, y=23.108, z=10.365$ for DNA, $x=-0.988, y=19.869, z=96.138$ for BSA site I and $x=0.111, y=-8.667, z=10.972$ for BSA site II. The LGA (Lamarckian genetic algorithm) was applied to find the best conformer of the compound during binding to DNA or BSA [50]. The fitness evaluation energy, number of runs and the maximum number of generations were set at 2,500,000,10 and 27,000, respectively. Other parameters were fixed as their initial values. The best binding poses of the metal complex with the lowest $\Delta \mathrm{G}^{0}$ in the interaction with DNA and BSA were obtained from Chimera 1.11.2 software and analyzed via Discovery Studio Visualizer 4.1 program.

\section{Results and discussion}

The newly designed Pd(II) complex, [Pd(bpy)(proli-dtc)] $\mathrm{NO}_{3}$, has been synthesized via the reaction between potassium salt of pyrroline dithiocarbamate and $\left[\mathrm{Pd}(\mathrm{bpy})\left(\mathrm{H}_{2} \mathrm{O}\right)_{2}\right]$ $\left(\mathrm{NO}_{3}\right)_{2}$. The (proli-dtc) ligand and the complex were characterized utilizing usual spectroscopic $\left({ }^{1} \mathrm{H}\right.$ NMR, FT-IR and $\mathrm{UV}-\mathrm{Vis}$ ) and non-spectroscopic (CHN analysis and conductivity measurement) methods gathered in "Preparation of the ligand and corresponding $\mathrm{Pd}$ (II) complex" section, as well as DFT calculation given in "Quantum chemical analysis" section. These methods indicate satisfactory results and good purity of the complex. Cytotoxicity evaluation of the title complex was investigated against K562 leukemia cells utilizing MTT assay. In addition, partition coefficient determination was done in octanol/water blend to check the lipophilicity of the compound. The computational and in-depth experimental studies about interactions of $\mathrm{Pd}$ (II) complex with biomolecules (DNA and BSA) were performed, and the findings of these approaches are discussed below. 


\section{Quantum chemical analysis}

Various geometries for the Pd(II) complex were drawn using Gauss View05 software, and all of them were optimized at DFT level of theory. All resulting optimized structures indicated that the $\mathrm{Pd}(\mathrm{II})$ metal ion is situated in a square-planar geometry and supports the proposed structure by experimental characterization ("Preparation of the ligand and corresponding Pd(II) complex" section). The optimized geometry of the Pd(II) complex is demonstrated in Fig. 2a. The energy and dipole moment values of the title complex were calculated as $-1,046,864.52 \mathrm{kcal} / \mathrm{mol}(-1668.31$ a.u $)$ and 3.68 Debye, respectively. The calculated bond lengths of $\mathrm{Pd}-\mathrm{N}$ $(2.08 \AA)$ and $\mathrm{Pd}-\mathrm{S}(2.32 \AA)$ are very comparable to the experimental findings of similar compounds. The $\mathrm{N}-\mathrm{Pd}-\mathrm{N}$ and $\mathrm{S}-\mathrm{Pd}-\mathrm{S}$ bond angles were calculated to be $79.11^{\circ}$ and $75.36^{\circ}$ while it was found to be $79.41^{\circ}$ and $88.67^{\circ}$ from the crystal structure of similar complex [51]. The obtained value for $\mathrm{S}-\mathrm{Pd}-\mathrm{S}$ bond angle in computational and experimental approaches are different due to the following: (i) in this study, the functional group (proli), which is connected to dithio is different than the functional group (1,2-benzene
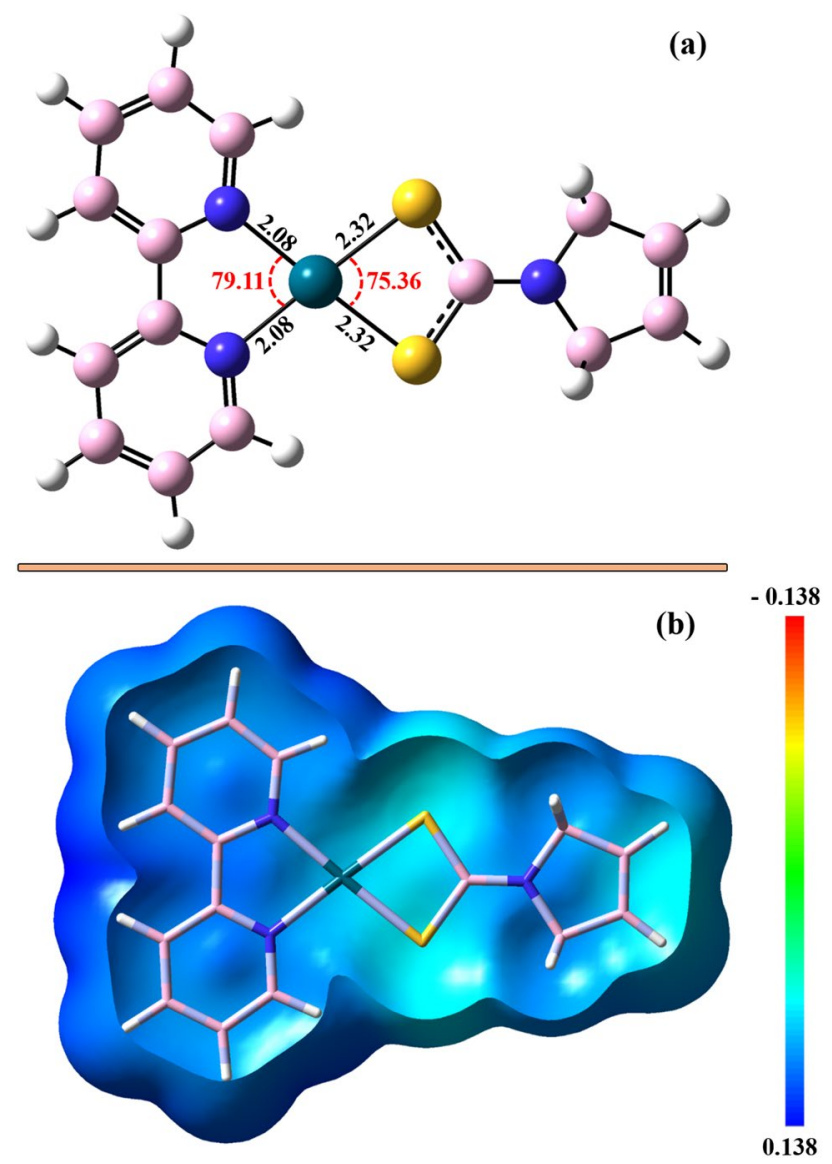

Fig. 2 The optimized structure (a) and cut from MEP plot of Pd(II) complex (b) dithiolate) in comparative complex [51], and (ii) theoretical procedure has been performed in the condition of the gas phase which may cause minor changes in the result.

\section{Molecular electrostatic potential analysis}

MEP surface is a visual tool for identifying negative, neutral and positive electrostatic potential domains in terms of color grading and relative polarity of a compound. It generally supplies key information about nucleophilic and electrophilic properties of semi-organic compounds. The negative electrostatic potential (red color region) corresponds to nucleophilic centers, while the positive electrostatic surface (blue color region) defines the electrophilic center in a 3D charge distribution of the system [52]. MEP surface is plotted over-optimized structure utilizing DFT method (B3LYP level in conjunction with aug-cc-pVTZ-pp basis set for Pd atom and 6-311G $(\mathrm{d}, \mathrm{p})$ basis set for $\mathrm{C}, \mathrm{H}, \mathrm{N}$, and $\mathrm{S}$ atoms) to predict the reactive locations of $\left[\mathrm{Pd}(\mathrm{bpy})(\right.$ proli-dtc) $] \mathrm{NO}_{3}$ complex for nucleophilic and electrophilic attacks. Figure $2 b$ represents the electrostatic potential contour map of the complex. It is evident that the positive potential density is primarily distributed over all complexes except sulfur atoms of dithiocarbamate, indicating that the complex is more appropriate for nucleophilic attack. On the other hand, the positive potential over bpy ligand makes it more favorable than proli-dtc ligand for nucleophilic attack.

\section{Quantum chemical calculation}

To investigate the quantum chemical parameters of the metal complex and its ligands, theoretical studies were conducted at the same level of theory as defined in "DFT calculation" section in the gas phase. Quantum chemical parameters including the highest occupied molecular orbital (HOMO), the lowest unoccupied molecular orbital (LUMO), and the HOMO-LUMO energy gap $(\Delta \mathrm{E})$ can be applied to evaluate the electronic structure, stability and chemical reactivity of a given compound [53]. The HOMO orbital denotes the ability of the compound to donate an electron, whereas LUMO shows its capability to act as an accepter. HOMO-LUMO energy diagram of $\mathrm{Pd}(\mathrm{II})$ complex and its related ligands, i.e. bpy and proli-dtc are obtained from the computational procedure and shown in Fig. 3. As shown in Fig. 3, the lower energy levels of frontier molecular orbitals of $[\mathrm{Pd}(\mathrm{bpy})$ (proli-dtc) $] \mathrm{NO}_{3}$ complex than free bpy and proli-dtc ligands make this complex more stable than alone ligands. For the complex, the HOMO orbital is completely over $\mathrm{Pd}(\mathrm{II})$ ion and $\mathrm{S}$ atoms of proli-dtc ligand while LUMO is mainly distributed on bpy ligand. Biological activity of the compounds and their $\Delta \mathrm{E}$ values can be mutually correlated. In the case of metal complex-DNA binding system, the DNA electron cloud mostly occupies HOMO, while the LUMO electron cloud is primarily spread over the 


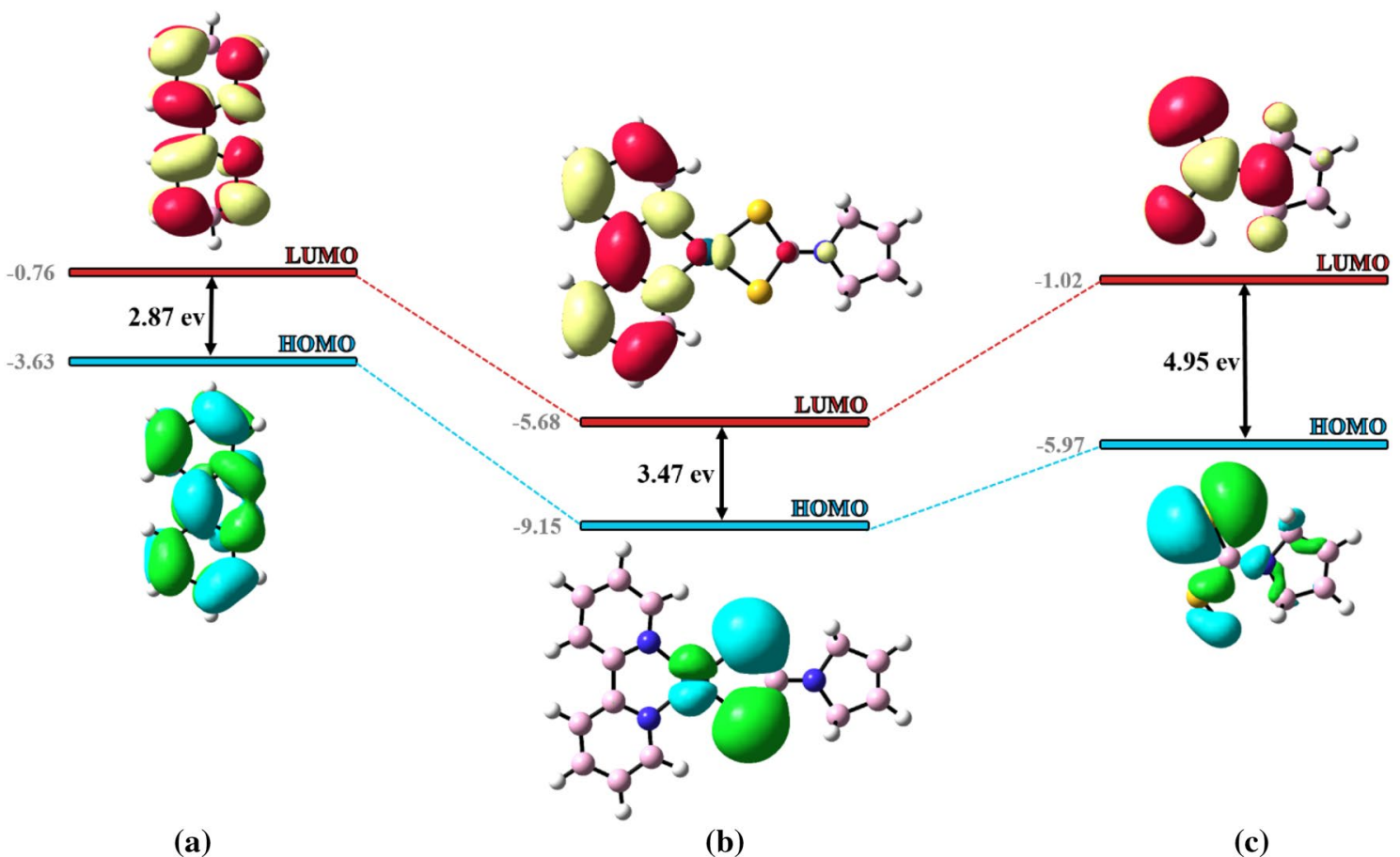

Fig. 3 Molecular orbital HOMO (lower) and LUMO (upper) of bpy (a), Pd(II) complex (b) and proli-dtc (c)

intercalative ligands of the metal complex such as bpy. By this form of electron cloud distribution, the overlap of HOMO (of DNA) and LUMO (of complex) orbitals is facilitated and leads to the intercalation of the complex within DNA [54].

Additional descriptors including absolute electronegativity $(\chi)$, absolute hardness $(\eta)$, absolute softness $(\sigma)$, chemical potential $(\mathrm{Pi})$, global electrophilicity $(\omega)$, and additional electronic charge $\left(\Delta \mathrm{N}_{\max }\right)$ are evaluated utilizing Eqs. (3-8) [55-57] and their relevant values are collected in Table 1.

$\chi=\frac{-\left(E_{\text {Номо }}+E_{L U M O}\right)}{2}$

$\eta=\frac{E_{L U M O}-E_{\text {НОMO }}}{2}$

$\sigma=\frac{1}{\eta}$

$P i=-\chi$
$\omega=\frac{P i^{2}}{2 \eta}$

$\Delta N_{\max }=\frac{-P i}{\eta}$

where $\chi$ indicates that a compound is a Lewis acid or a base. High $\chi$ is attributed to the Lewis acid and small $\chi$ value corresponds to the Lewis base $[58,59]$. As seen in Table 1, the newly made Pd(II) complex can be categorized as Lewis acid in comparison to the both ligands. From the value of $\eta$, the hard and soft molecules can be distinguished. Compounds with higher $\eta$ values are referred to hard and those with small magnitudes of $\eta$ are called soft. Soft compounds are more polarizable in comparison with the hard ones [58, 59]. The relatively higher $\eta$ value for proli-dtc ligand shows that it is chemically a hard compound in comparison to the $\operatorname{Pd}(\mathrm{II})$ complex and bpy ligand. Global electrophilicity $(\omega)$ is the ability of compound to absorb electrons from the system. The compounds with larger $\omega$ can form numbers of interactions with macromolecules. Since, the new Pd(II) complex
Table 1 Quantum chemical parameters of bpy, Pd(II) complex and proli-dtc (the values are given in $\mathrm{eV}$ )

\begin{tabular}{llllllllrl}
\hline compound & $\mathrm{E}_{\text {HОмО }}$ & $\mathrm{E}_{\text {LUMO }}$ & $\Delta \mathrm{E}$ & $\chi$ & $\eta$ & $\sigma$ & $\mathrm{Pi}$ & $\omega$ & $\Delta \mathrm{N}_{\max }$ \\
\hline bpy & -3.63 & -0.76 & 2.87 & 2.19 & 1.43 & 0.70 & -2.19 & 1.67 & 1.53 \\
Pd(II) complex & -9.15 & -5.68 & 3.47 & 7.41 & 1.73 & 0.58 & -7.41 & 15.87 & 4.28 \\
proli-dtc & -5.97 & -1.02 & 4.95 & 3.49 & 2.47 & 0.40 & -3.49 & 2.46 & 1.41 \\
\hline
\end{tabular}


has a larger value of $\omega$ than its related ligands (15.87-2.46 and 1.67 , respectively) there should be numerous interactions between the metal complex and biomolecules such as DNA and BSA [60]. In conclusion, the obtained values of the quantum chemical parameters point out the chemical reactivity of the $[\mathrm{Pd}(\mathrm{bpy})($ proli-dtc $)] \mathrm{NO}_{3}$ complex.

\section{Stability in solution}

Given that the potential anticancer agent should be stable in biological media, the stability of the synthesized Pd(II) complex in Tris-HCl buffer or double-distilled water was studied via UV-Vis spectra and analyzed before performing in vitro cytotoxic activity and DNA/BSA interaction experiments. The time-dependent $(0,5,10$, and $20 \mathrm{~h})$ spectroscopic analyses of the $\mathrm{Pd}(\mathrm{II})$ complex demonstrated that this complex is stable in biological aqueous solution at $37{ }^{\circ} \mathrm{C}$ because no changes in its spectra were observed (supplementary Fig. S1). Repeated experiments gave the same results.

\section{Lipophilicity determination}

Drug lipophilicity illustrates the capability of the compound to cross through the cell membranes and possesses a vital function in the determination of ADMET (absorption, distribution, metabolism, excretion, and toxicity) attributes [61, 62]. On the other hand, the cytotoxic activity of the compounds could be correlated with their aqueous solubility and lipophilicity (log P values) [63]. The greater lipophilicity of compounds can facilitate their uptake via phospholipid parts and greater hydrophilicity via protein parts of the cell membrane. Both amplify the biological activities of these compounds. Because more agents can enter the cancer cells, resulting in better action $[64,65]$. Here, the evaluated $\log \mathrm{P}$ value of Pd(II) complex is $-0.28 \pm 0.03$. This data represents that the lipophilicity of this complex is greater than cisplatin $(-2.28 \pm 0.07$ [66]). Moreover, the quantitative water solubility of the complex showed that it is much better soluble in water as compared with cisplatin. Furthermore, the liposolubility behavior of the Pd(II) complex can be explained on the basis of the presence of three hydrophobic ring moieties in the structure of the complex (see Fig. 1) and hydrophilicity of the metal complex on the basis of its ionic nature, i.e. a plus charge on its Pd ion. Thus, the present investigation is offering an exciting compound having a moderate hydrophobic as well as hydrophilic character. It is interesting that these observations are aligned with the results of cytotoxicity for $\left[\mathrm{Pd}(\mathrm{bpy})\right.$ (proli-dtc) $\mathrm{NO}_{3}$ complex (see "Cytotoxicity assay" section).

\section{Cytotoxicity assay}

Antiproliferative effect of Pd(II) agent at different concentrations $(0-70 \mu \mathrm{M})$ was studied on K562 leukemia cell line. Cell survival rate was measured after $24 \mathrm{~h}$ through MTT experiment. The $\mathrm{IC}_{50}$ of $\left[\mathrm{Pd}(\mathrm{bpy})(\right.$ proli-dtc) $] \mathrm{NO}_{3}$ complex was obtained from the diagram of $\%$ cell viability against the complex concentration. As can be observed in Fig. 4, the average of cancer cells survival rate decreases with increasing complex concentration. Furthermore, $\mathrm{IC}_{50}$ value after $24 \mathrm{~h}$ was obtained to be $11 \mu \mathrm{M}$. The $\mathrm{IC}_{50}$ value of cisplatin was determined to be $154 \mu \mathrm{M}$ under the similar experimental conditions. This value is higher than that of our newly made $\mathrm{Pd}(\mathrm{II})$ complex which indicates the inhibition potential of this new compound and its higher interaction affinity with DNA of K562 cell.

\section{Biomolecules interaction analysis}

\section{UV-Vis analysis}

Electronic absorption spectroscopy is a popular method to probe the conformational alterations of biomolecules and their interaction with antitumor transition metal complexes. The UV-Vis spectrum of BSA exhibits 2 bands, a strong peak around 220-240 $\mathrm{nm}$ attributed to the absorbance of $\alpha$-helix backbone of protein and a weak band near $280 \mathrm{~nm}$ because of the absorption of tryptophan, tyrosine and phenylalanine amino acids [67]. In these experiments, a specified amount of biomolecules was titrated via increasing amounts of the new Pd(II) complex (0-25.00 $\mu \mathrm{M}$ for CT-DNA and $0-48.27 \mu \mathrm{M}$ for BSA). The corresponding absorption spectra of CT-DNA and BSA are demonstrated in Fig. 5a and b. As seen in this figure, upon increasing the complex, CTDNA spectrum shows a red shift of about $5 \mathrm{~nm}$ with the

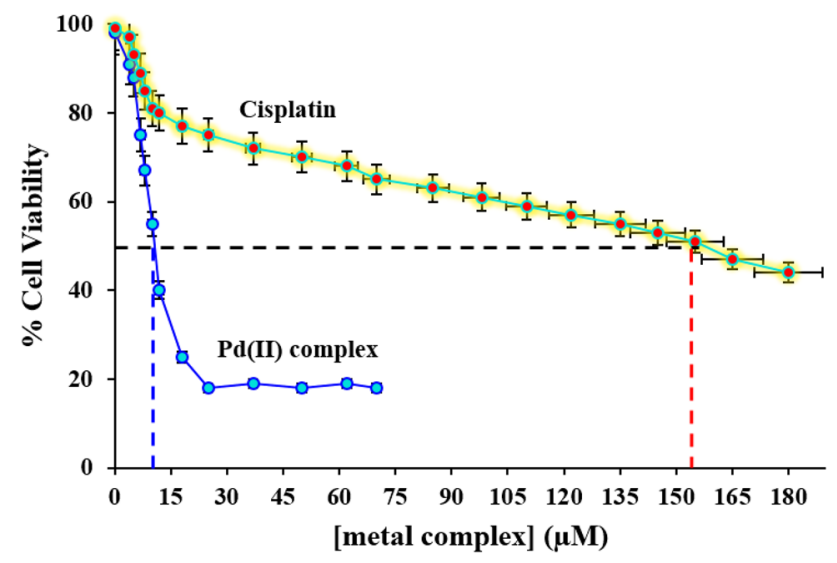

Fig. 4 Diagram demonstrating the effect of $[\mathrm{Pd}(\mathrm{bpy})($ proli-dtc $)] \mathrm{NO}_{3}$ and cisplatin on $\mathrm{K} 562$ cell lines. $\mathrm{IC}_{50}$ values were evaluated for $24 \mathrm{~h}$ agent action 

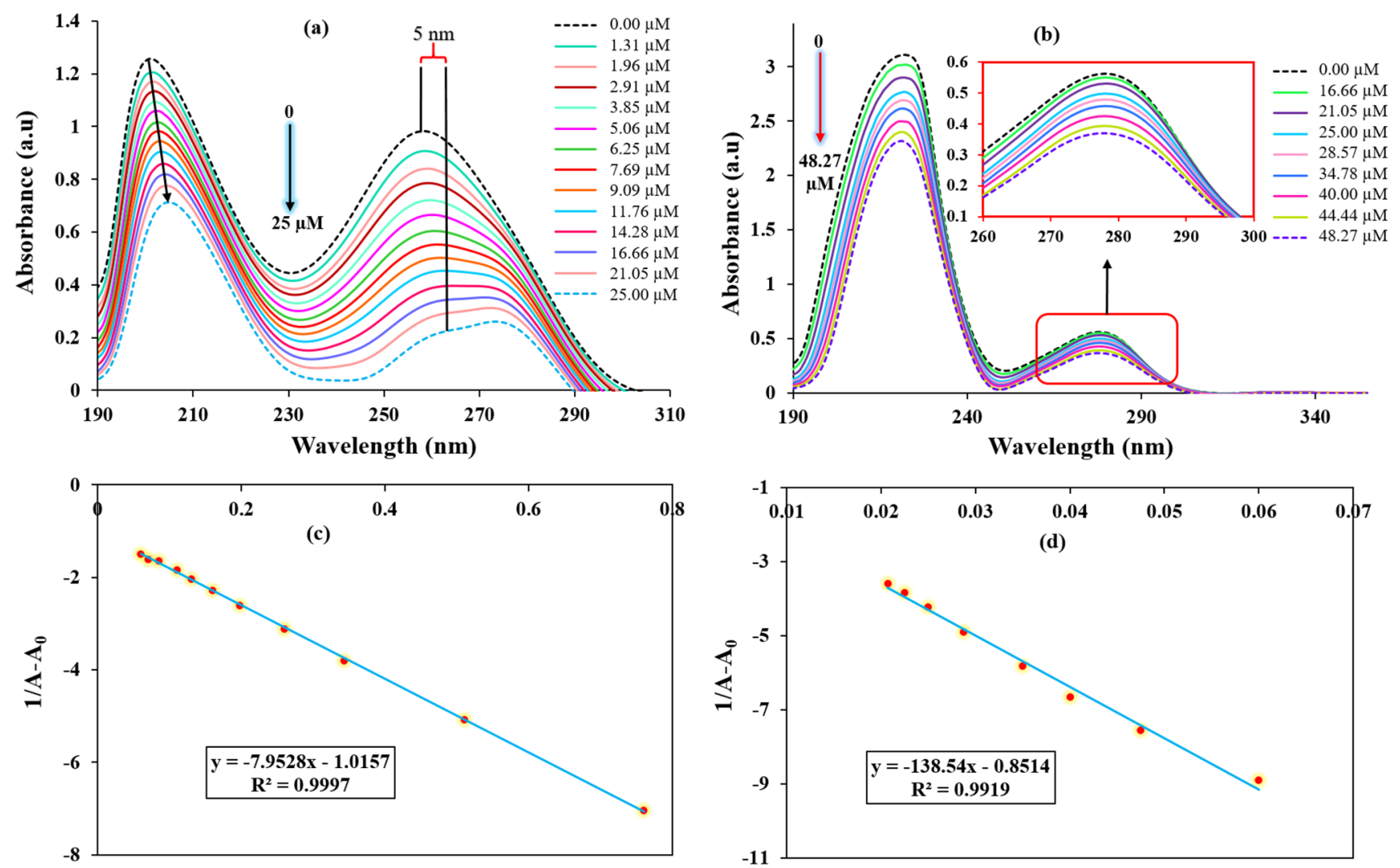

1/[complex]

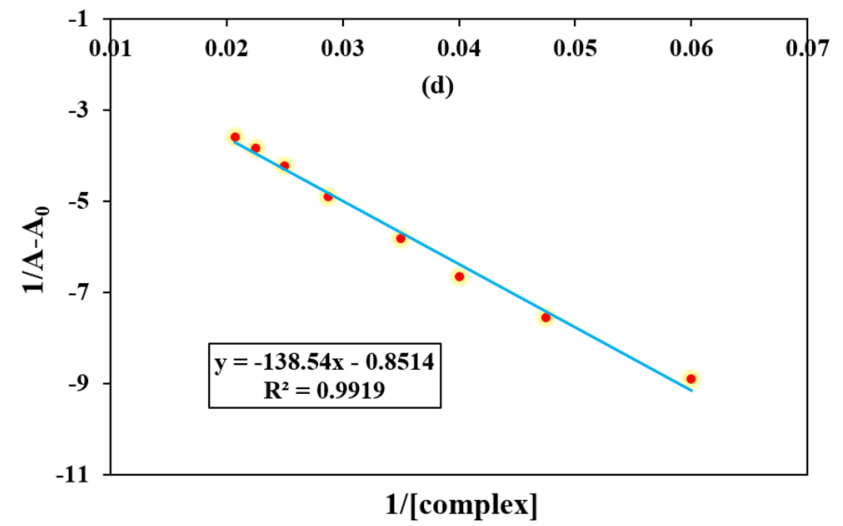

Fig. 5 Absorption spectra of CT-DNA a BSA $\mathbf{b}$ in Tris-HCl buffer upon addition of $\left[\mathrm{Pd}(\mathrm{bpy})(\right.$ proli-dtc) $] \mathrm{NO}_{3}$ complex. The arrow represents the direction of change in intensity upon increasing the con-

corresponding decrease in the peak absorbance at $260 \mathrm{~nm}$. It is obvious from Fig. 5b that BSA exhibits no shift in the peak position but there is a reduction in the absorption intensity at $280 \mathrm{~nm}$. These results illustrate the binding affinity of Pd(II) complex with both biomolecules.

We know that the binding of DNA with small molecules generally occurs through grooves, electrostatic and intercalative $\pi-\pi$ stacking interactions. Complexes with planar ligands often interact with DNA via intercalative mode, but those with non-planar ligands may interact with DNA via nonintercalation binding. Since bpy ligand of the new Pd(II) complex is about planar, so intercalation might occur for its binding with DNA. Intercalation happens when $\pi^{*}$ orbital of metal complex couples with $\pi$ orbital of the base pairs (purine/pyrimidine) of DNA. It may result in reducing $\pi \rightarrow \pi^{*}$ transition energy of the DNA-bearing intercalator. Consequently, a red shift in the maximum wavelength position (bathochromism) along with a reduction in its absorption intensity (hypochromism) may observed [68]. The resulted hypochromicity for the interaction of $[\mathrm{Pd}(\mathrm{bpy})$ (proli-dtc) $] \mathrm{NO}_{3}$ with CT-DNA is $44.8 \%$ and for BSA is $41.2 \%$.

centration of the $\mathrm{Pd}(\mathrm{II})$ complex (c and d: plot of $1 /\left(\mathrm{A}-\mathrm{A}_{0}\right)$ against $1 /$ [complex] to obtain $K_{a p p}$ )

Using Eq. (2) and the electronic absorption data, the apparent binding constant $\left(K_{a p p}\right)$ for the binding of the title complex to CT-DNA/BSA was calculated. From the linear relationship between $1 /\left(A-A_{0}\right)$ and $1 /$ [complex] with a slope equal to $1 / K_{\text {app }}\left(A-A_{0}\right)$ and intercept equals to $1 /(A-$ $\left.A_{0}\right)$, the magnitude of $K_{a p p}$ was obtained via dividing the intercept by the slope (Fig. 5c for DNA and Fig. 5d for BSA). As illustrated in Table 2, the value of $\mathrm{K}_{\text {app }}$ for the new complex $\left(1.28 \times 10^{5} \mathrm{M}^{-1}\right)$ with CT-DNA is a bit higher than that of $\mathrm{EB}\left(K_{a p p}=(1.23 \pm 0.07) \times 10^{5} \mathrm{M}^{-1}[69]\right)$. This indicates perhaps the binding mode of this metal complex to CT-DNA should be intercalation, resembling to that of EB. Also, $K_{a p p}$ value of the Pd(II) complex in its interaction with DNA $\left(1.28 \times 10^{5} \mathrm{M}^{-1}\right)$ is higher than with BSA $\left(6.14 \times 10^{3} \mathrm{M}^{-1}\right)$. These results show that binding affinity of $\left[\mathrm{Pd}(\mathrm{bpy})(\right.$ proli-dtc) $] \mathrm{NO}_{3}$ with CT-DNA is more than that of BSA. Furthermore, the $\Delta G^{\circ}$ for the interaction of the Pd(II) complex to CT-DNA and BSA was calculated to be -6.99 and $-5.18 \mathrm{kcal} / \mathrm{mol}$, respectively. The negative values of $\Delta \mathrm{G}^{\circ}$ show the spontaneity of compound-DNA or -BSA interactions and support the more binding affinity of the complex with CT-DNA being observed from $K_{a p p}$ values. 
Table 2 Apparent binding constants, change of free energy, \% hypochromicity, and midpoint transition constant for the interaction between the $\left[\mathrm{Pd}(\mathrm{bpy})(\right.$ proli-dtc) $] \mathrm{NO}_{3}$ complex with CT-DNA and BSA

\begin{tabular}{llllll}
\hline & $\mathrm{T}(\mathrm{K})$ & $\mathrm{K}_{\text {app }}\left(\mathrm{M}^{-1}\right)$ & $\Delta \mathrm{G}^{\circ}(\mathrm{Kcal} / \mathrm{mol})$ & $\mathrm{H}(\%)$ & {$[\mathrm{L}]_{1 / 2}(\mathrm{mM})$} \\
\hline CT-DNA binding & 300 & $1.28 \times 10^{5}$ & -6.99 & $44.8 \%$ & 0.0075 \\
BSA binding & 300 & $6.14 \times 10^{3}$ & -5.18 & $41.2 \%$ & 0.037 \\
\hline
\end{tabular}

During the interaction of the compound with CT-DNA or BSA, some conformational changes happen in the corresponding macromolecules, which are regarded as refolding or unfolding. Active components toward UV light in DNA are purine and pyrimidine bases and for BSA are tryptophan, tyrosine and phenylalanine amino acid residues. Unfolding occurs when the conformational changes are such that the active components are available to the UV light, as a results by addition of metal complex to biomolecules, the absorption intensity may increase. On the other hand, when refolding happens the active components are less exposed to the UV-Vis waves or conformational changes lead to hiding of absorbing groups. In the latter case, the absorption intensity of macromolecules should decrease upon increasing complex concentration. Since by addition of title complex to DNA and BSA, the absorbance intensity decreases, so their conformational lose happens through refolding. In order to calculate the denaturant concentration at which half of the CT-DNA or BSA is refolded ( $\mathrm{L}_{1 / 2}$, the midpoint transition), the alterations in the absorption at $260 \mathrm{~nm}$ for CT-DNA and at $280 \mathrm{~nm}$ for BSA were plotted versus different concentrations of the Pd(II) complex and are represented in Fig. 6a and $b$, respectively. These plots show that upon rising the complex concentration, the absorption of CT-DNA or BSA decreases. From Fig. 6 , the values of $\mathrm{L}_{1 / 2}$ for the interaction of $\left[\mathrm{Pd}(\mathrm{bpy})(\right.$ proli-dtc) $] \mathrm{NO}_{3}$ with the two biomolecules were obtained and are listed in Table 2. As observed in this table, a low concentration of the new $\operatorname{Pd}(\mathrm{II})$ complex (small $\mathrm{L}_{1 / 2}$ ) is enough to have an efficient interaction with DNA or BSA and probably will show lower side effects if used in physiological systems.

\section{Fluorescence spectroscopic analysis}

Fluorescence quenching mechanisms of $E B+C T-D N A$ and $\mathrm{BSA}$ by $\left[\mathrm{Pd}(\mathrm{bpy})(\right.$ proli-dtc) $] \mathrm{NO}_{3}$ Fluorescence spectroscopy, an appropriate procedure for biomolecule-metal complex binding studies, provides details about the number of binding sites, binding mechanism, binding constants, thermodynamic parameters, and intermolecular distances. The interaction of $\left[\mathrm{Pd}(\mathrm{bpy})(\right.$ proli-dtc) $] \mathrm{NO}_{3}$ with CT-DNA and BSA were investigated at various temperatures of 293 , 300 , and $310 \mathrm{~K}$ via the fluorescence spectral measurement. EB is one of the most important fluorescence probes which can intercalate into the base pairs of CT-DNA and can effectively increase the fluorescence emission intensity of EB+CT-DNA (Fig. 7a). The metal complex can substitute EB in interacting with CT-DNA, thereby reducing the emission intensity of EB+CT-DNA sample [70]. As illustrated in Fig. 7a, the emission intensity of EB $+\mathrm{CT}$ DNA was gradually quenched with rising Pd(II) complex concentration. The results indicate that the emission profile at $\lambda_{\max }=604 \mathrm{~nm}$ reveals hypochromism when the concentration of metal complex increases, demonstrating that the increased Pd(II) complex could competitively interact with CT-DNA and substitute EB in the EB + CT-DNA sample
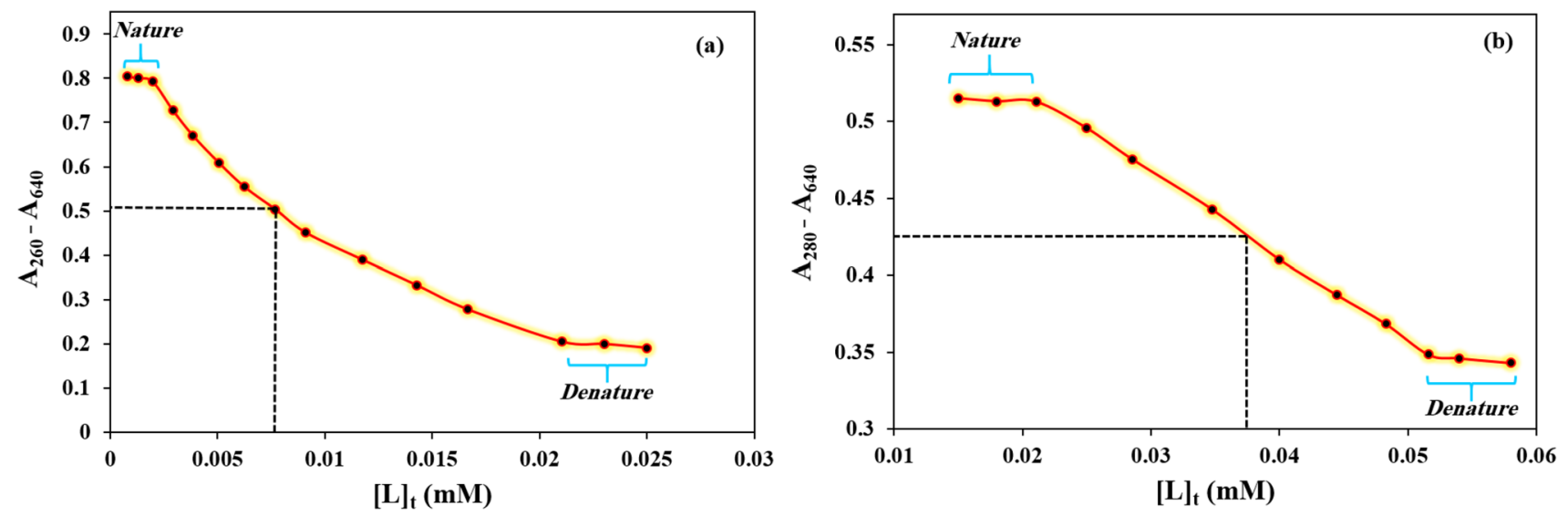

Fig. 6 The changes of absorbance of CT-DNA (a) and BSA (b) at $\lambda_{\max }=260$ and $280 \mathrm{~nm}$ respectively due to increasing the concentration of $\left[\mathrm{Pd}(\mathrm{bpy})(\right.$ proli-dtc) $) \mathrm{NO}_{3}$ 

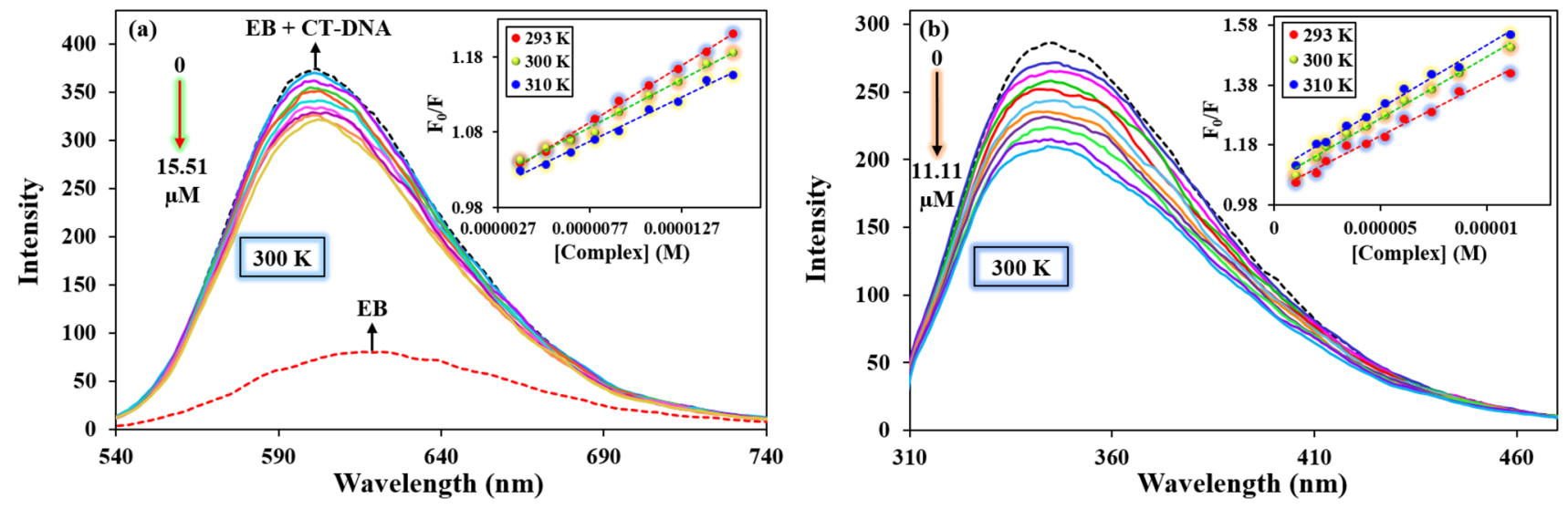

Fig. 7 Fluorescence spectra of EB + CT-DNA (a) and BSA (b) systems in the absence and presence of rising volumes of [Pd(bpy)(proli-dtc)] $\mathrm{NO}_{3}$ at $300 \mathrm{~K}$. Insets: the plots of $F_{0} / F$ vs [complex] for EB +CT-DNA/BSA titration at three temperatures of 293,300 and $310 \mathrm{~K}$

[71]. The quenching of emission intensity of $\mathrm{EB}+\mathrm{CT}$ DNA via complex suggests the strong interaction of metal complex toward CT-DNA. Thus, the binding mode of the $\left[\mathrm{Pd}(\right.$ bpy)(proli-dtc) $] \mathrm{NO}_{3}$ complex to CT-DNA is likely to be intercalation, which is aligned with the finding of UVVis experiment and can be further verified via viscosity measurements too. The aforementioned methods have been applied for some metal complexes [72].

BSA structure possesses three intrinsic fluorophores, namely phenylalanine, tyrosine and tryptophan. BSA inherent fluorescence is generally due to tryptophan residue alone, as phenylalanine possesses a very poor quantum yield and tyrosine emission is nearly completely quenched if ionized [73]. Figure $7 \mathrm{~b}$ illustrates the changes in the pattern of BSA fluorescence upon a consecutive increment of metal complex. The fluorescence intensity of free BSA is frequently decreased at $\lambda_{\max }=345 \mathrm{~nm}$ with the rising volume of the Pd(II) complex due to probable alterations in BSA tryptophan residues, which implies an interaction between [Pd(bpy)(proli-dtc) $] \mathrm{NO}_{3}$ and BSA [74].

The fluorescence emission spectra were analyzed under three temperatures via Stern-Volmer equation which is also very useful to elucidate the quenching mechanism type in the DNA/BSA binding system, given as Eq. (9) $[75,76]$ :

$\frac{F_{0}}{F}=1+K_{S V}[$ complex $]=1+k_{q} \tau_{0}[$ complex $]$

$k_{q}=\frac{K_{S V}}{\tau_{0}}$

where $F$ and $F_{0}$ denote the fluorescence intensities of fluorophore (CT-DNA-EB or BSA) in the presence and absence of quencher (metal complex). $K_{S V}, k_{q}, \tau_{0}$ and [complex] are Stern-Volmer quenching constant, fluorophore quenching constant, the fluorescent lifetime of bio-macromolecule in the excited state without quencher $\left(10^{-8} \mathrm{~s}\right)$ and quencher concentration, respectively. The $K_{s v}$ values were evaluated from the slope of a plot between $F_{0} / F$ (y-axis) and [complex] (x-axis). Further, the $k_{q}$ values were calculated via utilizing Eq. (10).

Generally, the quenching mechanisms are known as dynamic, static and dynamic-static combinations, which can be determined by calculating the quenching constant of a binding system and following its behavior under changing temperatures [77]. Dynamic quenching happens via the collision of fluorophore with the quencher at the excited state and static is created through the formation of a non-fluorescent fluorophore-quencher complex at the ground state [78]. For dynamic quenching, the quenching rate constant enhances with temperature rise while the reverse is correct for the static quenching [79]. In addition, in dynamic quenching, the maximum quenching constant of diverse quenchers with the biopolymer is close to $2 \times 10^{10} \mathrm{~L} \mathrm{~mol}^{-1} \mathrm{~s}^{-1}$ [80]. The Stern-Volmer plots of the metal complex-CT-DNA/BSA systems at different temperatures are given in Fig. 7 (insets) and demonstrate a well linear relationship between $F_{0} / F$ and [complex]. As given in Table 3, the $\mathrm{K}_{\mathrm{Sv}}$ values for $\mathrm{Pd}(\mathrm{II})$ complex-CT-DNA system decrease by raising the temperature, and for complex-BSA system increase gradually with rising the temperature from 293 to $310 \mathrm{~K}$, indicating that the quenching mechanism for the complex-CT-DNA is static and for complex-BSA system is dynamic. Moreover, the obtained values of $k_{q}$ for both systems are as large as 100fold than the maximum scatter quenching collision constant of the biomolecule $\left(2 \times 10^{10} \mathrm{~L} \mathrm{~mol}^{-1} \mathrm{~s}^{-1}\right)$, which suggests the occurrence of static mechanism for both biomacromolecule systems. As a result, the quenching mechanism for DNA binding system is probably static and for BSA binding system is the combination of dynamic and static. This phenomenon has been observed in some literatures in the case of protein binding [82, 82, 83]. 
Table 3 Binding and thermodynamic parameters of $[\mathrm{Pd}(\mathrm{bpy})($ proli-dtc $)] \mathrm{NO}_{3}$ complex with CT-DNA and BSA obtained from fluorescence emission experiments at various temperatures

\begin{tabular}{lllllllll}
\hline Experiments & $\mathrm{T}(\mathrm{K})$ & $K s v \times 10^{4}\left(\mathrm{M}^{-1}\right)$ & $k_{q} \times 10^{12}\left(\mathrm{M}^{-1} \mathrm{~s}^{-1}\right)$ & $K_{b}\left(\mathrm{M}^{-1}\right)$ & $n$ & $\Delta G^{\mathrm{o}}(\mathrm{kcal} / \mathrm{mol})$ & $\Delta H^{\mathrm{o}}(\mathrm{kcal} / \mathrm{mol})$ & $\Delta S^{\mathrm{o}}(\mathrm{kcal} / \mathrm{mol})$ \\
\hline DNA binding & 293 & $1.51 \pm 0.03$ & $1.51 \pm 0.03$ & $(2.43 \pm 0.05) \times 10^{5}$ & $1.26 \pm 0.01$ & $-7.28 \pm 0.06$ & \\
& 300 & $1.28 \pm 0.03$ & $1.28 \pm 0.03$ & $(3.08 \pm 0.04) \times 10^{5}$ & $1.28 \pm 0.01$ & $-7.66 \pm 0.06$ & $8.54 \pm 0.08$ & $0.05 \pm 0.001$ \\
& 310 & $1.17 \pm 0.02$ & $1.17 \pm 0.02$ & $(5.37 \pm 0.05) \times 10^{5}$ & $1.35 \pm 0.02$ & $-8.20 \pm 0.05$ & & \\
BSA binding & 293 & $3.62 \pm 0.02$ & $3.62 \pm 0.02$ & $(6.91 \pm 0.03) \times 10^{3}$ & $0.85 \pm 0.03$ & $-5.16 \pm 0.05$ & & \\
& 300 & $4.12 \pm 0.04$ & $4.12 \pm 0.04$ & $(2.90 \pm 0.03) \times 10^{3}$ & $0.76 \pm 0.02$ & $-4.74 \pm 0.06$ & $-22.59 \pm 0.05$ & $-0.06 \pm 0.001$ \\
& 310 & $4.20 \pm 0.03$ & $4.20 \pm 0.03$ & $(0.82 \pm 0.03) \times 10^{3}$ & $0.64 \pm 0.02$ & $-4.14 \pm 0.06$ & & \\
\hline
\end{tabular}

All results were expressed as the mean \pm standard deviation of three independent experiments

Binding constants and binding sites The binding constant $\left(K_{b}\right)$ of the complex with both the macromolecules as well as the number of binding sites (n) per CT-DNA or BSA molecule can be evaluated from the slope and intercept in the plots of $\log \left[\left(F_{0}-F\right) / F\right]$ against log [complex] (Fig. 8) based on the Eq. (11) [84]_ENREF_81:

$\log \left(\frac{F_{0}-F}{F}\right)=\log K_{b}+n \log [$ complex $]$

The obtained values of $\mathrm{n}$ and $\mathrm{K}_{\mathrm{b}}$ for DNA and BSA binding at three separate temperatures are displayed in Table 3. The $\mathrm{n}$ value for DNA or BSA binding system was calculated to be $\sim 1$ which refers to the existence of one binding site on the CT-DNA or BSA for [Pd(bpy)(proli-dtc) $\mathrm{NO}_{3} . K_{b}$ was found to be of the order of $10^{5}$ for DNA interaction, representing strong interaction between $\mathrm{Pd}(\mathrm{II})$ complex and CT-DNA. In addition, rising $K_{b}$ value with increasing temperature obviously illustrates that the complex-CT-DNA system can achieve more stability at high temperatures. In contrast, $K_{b}$ value for BSA binding was found to fall into the order of $10^{3}$, which demonstrates a moderate binding affinity between Pd(II) complex and BSA. On the other hand, the

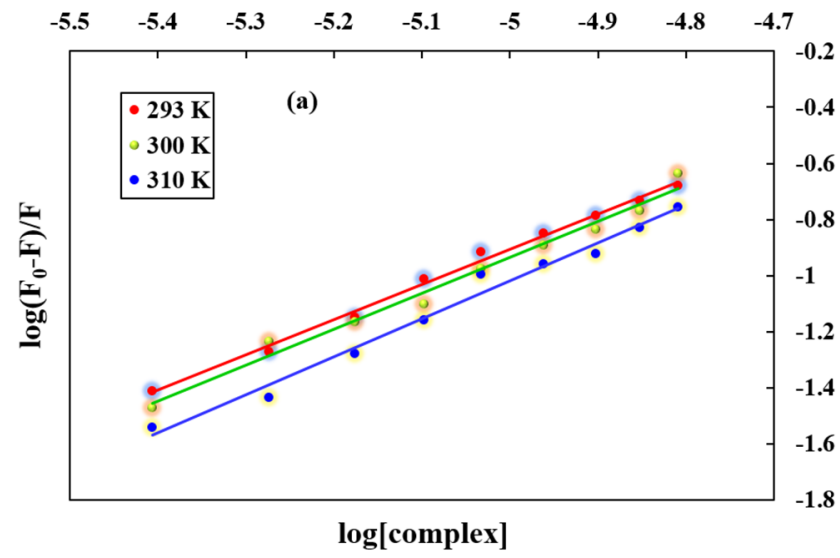

decrease in $\mathrm{K}_{\mathrm{b}}$ value with rising temperature confirms the loss of stability in complex-BSA system at high temperature [85]. These findings show that the obtained $K_{b}$ values from fluorescence data $\left(3.08 \times 10^{5} \mathrm{M}^{-1}\right.$ for DNA interaction and $2.9 \times 10^{3} \mathrm{M}^{-1}$ for BSA interaction) and the obtained $\mathrm{K}_{\mathrm{app}}$ from absorption titrations $\left(1.28 \times 10^{5} \mathrm{M}^{-1}\right.$ for DNA interaction and $6.14 \times 10^{3} \mathrm{M}^{-1}$ for BSA interaction) at $300 \mathrm{~K}$ are nearly in the same order and mutually supportive. Therefore, according to the DNA binding results, it is again assumed that the $[\mathrm{Pd}(\mathrm{bpy})$ (proli-dtc) $] \mathrm{NO}_{3}$ complex may be intercalated between the CT-DNA base pairs.

Thermodynamics parameters and binding forces The forces acting in the $\left[\mathrm{Pd}(\mathrm{bpy})(\right.$ proli-dtc) $] \mathrm{NO}_{3}$-biomolecule (CT/DNA or BSA) interaction can be further identified utilizing thermodynamic parameters, i.e. binding enthalpy $\left(\Delta H^{\circ}\right)$, entropy $\left(\Delta S^{\circ}\right)$ and Gibbs free energy $\left(\Delta G^{\circ}\right)$ [86]. These forces mainly involve hydrogen bonding, electrostatic attraction, hydrophobic, and van der Waals forces [87]. It is widely accepted that the relation between thermodynamic parameters and binding forces are as follows: (i) the major force is hydrophobic if $\Delta H^{\circ}>0$ and $\Delta S^{\circ}>0$, (ii) the binding is dominated by the electrostatic attraction if $\Delta H^{\circ}<0$

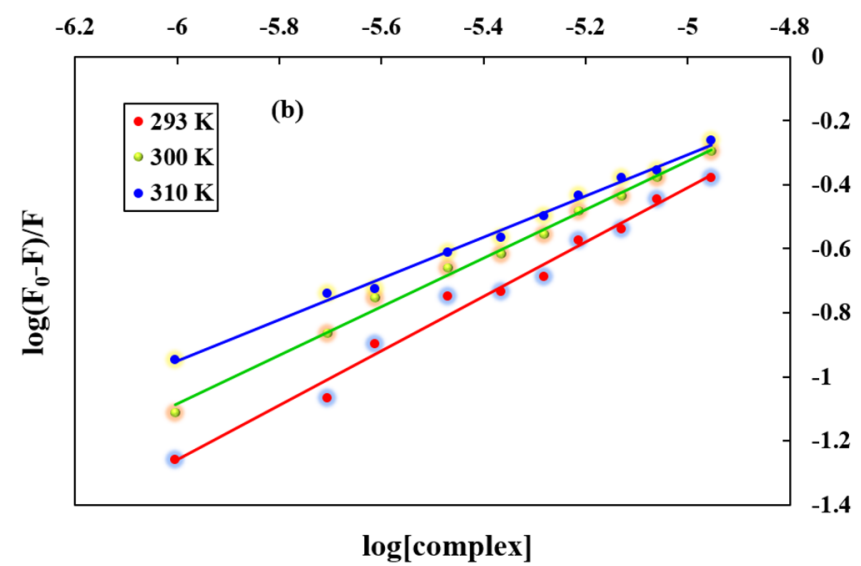

Fig. 8 Double-log plot for the interaction of [Pd(bpy)(proli-dtc)]: CT-DNA (a)/BSA (b) at three temperatures 
or $\Delta S^{\circ}>0$, and (iii) van der Waals force and/or hydrogen bonds will play the prominent role if $\Delta H^{\circ}<0$ and $\Delta S^{\circ}<0$ [88]. Using the obtained $\mathrm{K}_{\mathrm{b}}$ values from Eq. (11) at different temperatures, thermodynamic parameters for both biological systems can be computed via Eqs. (12), (13) and (14).

$\Delta G^{\circ}=-R T \ln K_{b}$

$\Delta G^{\circ}=\Delta H^{\circ}-T \Delta S^{\circ}$

$\ln K_{b}=-\frac{\Delta G^{\circ}}{R T}=-\frac{\Delta H^{\circ}}{R}\left(\frac{1}{T}\right)+\frac{\Delta S^{\circ}}{R}$

According to Eq. (12), $\Delta G^{\circ}$ at three temperatures of 293, 300 and $310 \mathrm{~K}$ were calculated. On the other hand, by plotting $\ln K_{b}$ versus $1 / \mathrm{T}$ (Eq. (14), Fig. 9), $\Delta H^{\circ}$ and $\Delta S^{\circ}$ values were calculated from the slope, i.e. $-\Delta H^{\circ} / R$ and intercept, i.e. $\Delta \mathrm{S}^{\circ} / \mathrm{R}$, respectively. The findings have been summarized in Table 3. $\Delta G^{\circ}<0$ for both biomolecule binding systems means that the binding of $\left[\mathrm{Pd}(\mathrm{bpy})(\right.$ proli-dtc) $] \mathrm{NO}_{3}$ complex with DNA and BSA are spontaneous processes [89]. In the case of DNA binding, the evidence that $\Delta H^{\circ}$ and $\Delta S^{\circ}$ are both positive $(>0)$ indicates a significant contribution of hydrophobic forces between Pd(II) complex and CT-DNA, and so the reaction is entropy-driven [80]. This result is in agreement with the reality that the metal complex is intercalated or at least partially intercalated in CT-DNA since its planner moiety (i.e. bpy) is proper for the insertion between CT-DNA base pairs. On the other hand, when a compound is inserted between the base pairs of CT-DNA, the molecular orbitals of base pairs and compound can overlap and lead to the formation of hydrophobic forces of $\pi-\pi$ staking type. In BSA binding, the values of $\Delta H^{\circ}$ and $\Delta S^{\circ}$ are both negative $(<0)$, demonstrating van der Waals force and/or hydrogen bonds play the key role in the linking of $\mathrm{Pd}(\mathrm{II})$ complex to BSA, so the reaction is enthalpy-driven and $\left|\Delta H^{\circ}\right|>\left|T \Delta S^{\circ}\right|$ [24]. This observation is also interesting since BSA is a carrier (host) biomolecule and its interaction forces with the guest should be so appropriate that could easily release it beside the target on the bases of phenomena like: concentration gradient, $\mathrm{pH}$ changes, solvent (hydrophilic/lipophilic) influence and the difference between ionic strength around uploaded and downloading area of guest molecule, etc. To validate the type of interactions involved in the binding of $\left[\mathrm{Pd}(\mathrm{bpy})(\right.$ proli-dtc) $] \mathrm{NO}_{3}$ complex with DNA and BSA, in-silico molecular docking will be implemented in the "Docking simulation" section.

\section{Energy transfer calculation}

FRET, one of the most relevant techniques to measure the average molecular distance in biological systems, is defined as a molecular ruler [90]. According to the Förster theory, generally, FRET occurs under 3 situations: (i) emission of fluorescence by donor molecule, (ii) the UV-Vis spectrum of acceptor molecule overlaps with the fluorescence emission spectrum of the donor molecule; and (iii) the average distance between acceptor and donor should be in the range of 2-8 nm [75]. Figure 10 demonstrates the overlap of UV spectrum of acceptor ([Pd(bpy)(proli-dtc) $] \mathrm{NO}_{3}$ ) with the fluorescence spectrum of donor (BSA) which is known as $J(\lambda)$, obviously represents FRET occurs in the complex-protein system. $E$, the extent of energy transfer, is attributed to the distance from donor to acceptor $(r)$ and $R_{0}$ (the critical energy transfer distance at $E=50 \%$, which can be calculated from the following Eqs. (15-17) [91]:

$$
\begin{aligned}
& E=\frac{R_{0}^{6}}{R_{0}^{6}+r_{0}^{6}}=1-\frac{F}{F_{0}} \\
& R_{0}^{6}=8.79 \times 10^{-25}\left[K^{2} N^{-4} \emptyset J(\lambda)\right]
\end{aligned}
$$
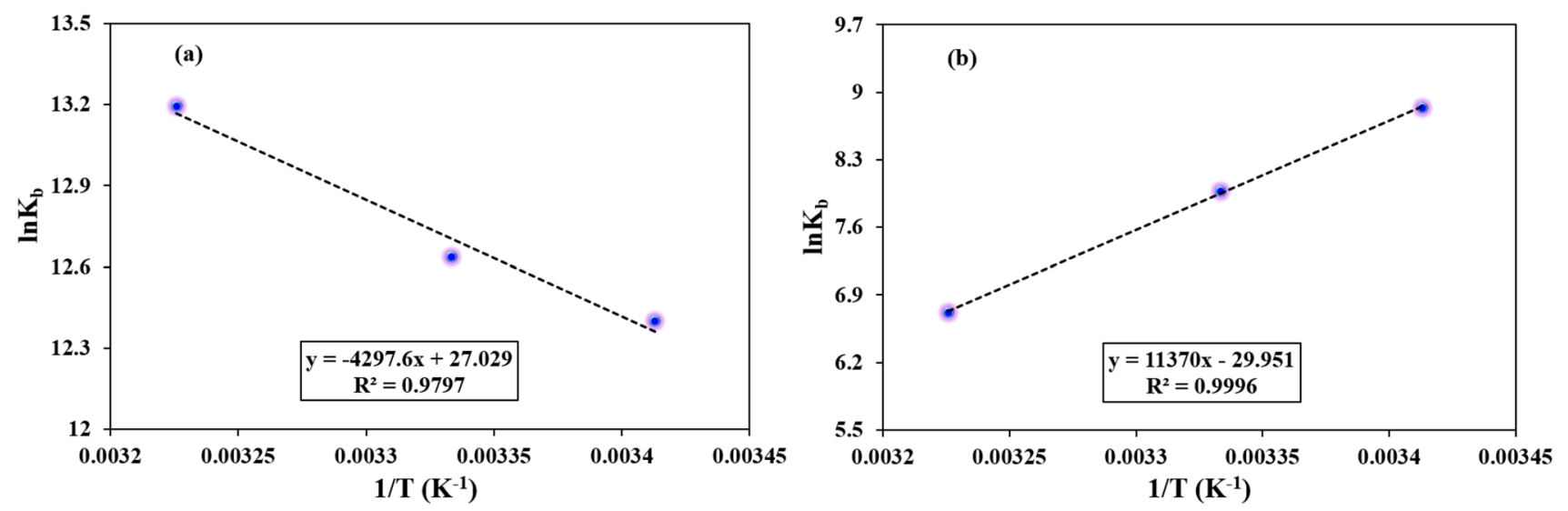

Fig. 9 The van't Hoff plot for [Pd(bpy)(proli-dtc)]:CT-DNA (a) and BSA (b) binding systems at 293, 300 and $310 \mathrm{~K}$ 


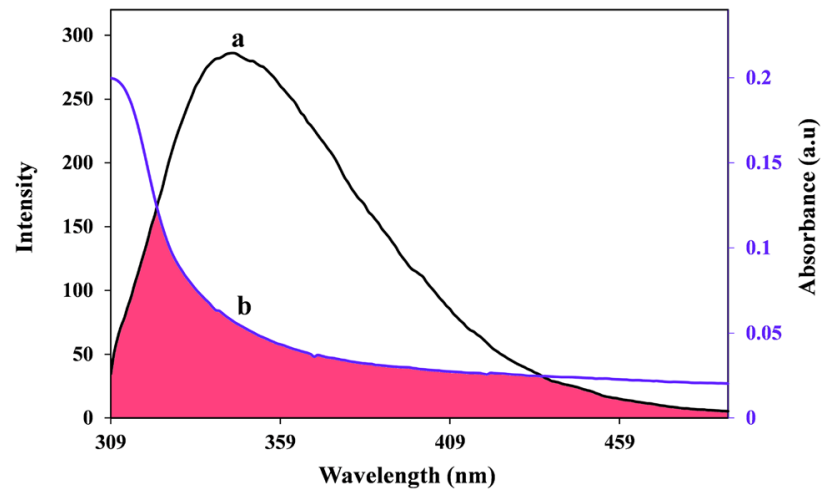

Fig. 10 The overlap of fluorescence emission spectrum of BSA (a) with UV-Vis spectrum of $\left[\mathrm{Pd}(\mathrm{bpy})(\right.$ proli-dtc) $] \mathrm{NO}_{3}$ (b). The concentrations of BSA and metal complex were equal to $10 \mu \mathrm{M}$

$J(\lambda)=\frac{\int_{0}^{\infty} F(\lambda) \varepsilon(\lambda) \lambda^{4} d \lambda}{\int_{0}^{\infty} F(\lambda) d \lambda}$

where $F_{0}$ and $F$ are defined as the emission intensities of BSA without and with the metal complex, $k^{2}$ is spatial orientation factor from donor to acceptor which equals to $2 / 3$ for BSA-complex system, $N$ expresses the refractive index of the medium (for BSA $=1.36$ ), $\varphi$ is the donor quantum yield, i.e. 0.118 for BSA [92], $F(\lambda)$ and $\varepsilon(\lambda)$ are the fluorescence intensity of BSA at the wavelength of $\lambda$ and the molar absorbance coefficient of the complex, respectively.

Utilizing above-mentioned equations, it is feasible to evaluate $J(\lambda), R_{0}, E$ and $r$ for BSA-metal complex interaction. The obtained data are summarized in Table 4 . The average distance $r=2.76(<8 \mathrm{~nm})$ is within $2-8 \mathrm{~nm}$ and $0.5 R_{0}<\mathrm{r}<1.5$ $R_{0}[93]$ showing that the energy transfer from BSA to [Pd(bpy) (proli-dtc) $\mathrm{NO}_{3}$ could occur with a high possibility. The FRET finding, similar to the obtained result from fluorescence spectroscopy, demonstrated again that the quenching mechanism in [Pd(bpy)(proli-dtc) $\mathrm{NO}_{3}$-BSA binding system is static type in high concentration [94].

\section{Agarose gel electrophoresis}

DNA binding activity of the new Pd (II) complex was studied by electrophoresis method. Gel electrophoresis assay is a method that is based on the CT-DNA movement on the gel tank due to the electric field. The rate of migration depends on the mass, charge, shape, and topological properties of the compound flowing on the agarose gel. DNA has a negative charge and moves on the agarose gel matrix toward the positive anode. Figure 11 demonstrates the electrophoretic mobility of CT-DNA toward positive electrode in the absence and presence of various concentrations of $[\mathrm{Pd}(\mathrm{bpy})($ proli-dtc $)] \mathrm{NO}_{3}$. As the complex concentration increases, more delay and up-shift are observed for DNA in the agarose gel. This could be attributed to the decrease of its negative charge or increasing its mass after binding with $\mathrm{Pd}(\mathrm{II})$ complex. Furthermore, from this figure it is obvious that the intensity of the lanes measured for EB + CT-DNA after interaction with different concentrations of $\left[\mathrm{Pd}(\mathrm{bpy})(\right.$ proli-dtc) $] \mathrm{NO}_{3}$ have been decreased in comparison to the lane of free EB + CT-DNA. The reduce in the intensity of observed lanes of treated EB + CT-DNA is believed to be owing to its quenching of fluorescence due to the presence of complex. As the concentration of complex increases, more fluorescence quenching happens, therefore, the intensity decreases more in comparison to free EB+CT-DNA.

\section{Viscosity measurement}

Howbeit photophysical probes provide required evidence to validate the binding mode of metal complex to DNA, viscosity measurement is considered to be a critical and least obscure method in DNA-binding experiments. Intercalating agents lead to the lengthening of the double helix due to the insertion between DNA base pairs which further causes an

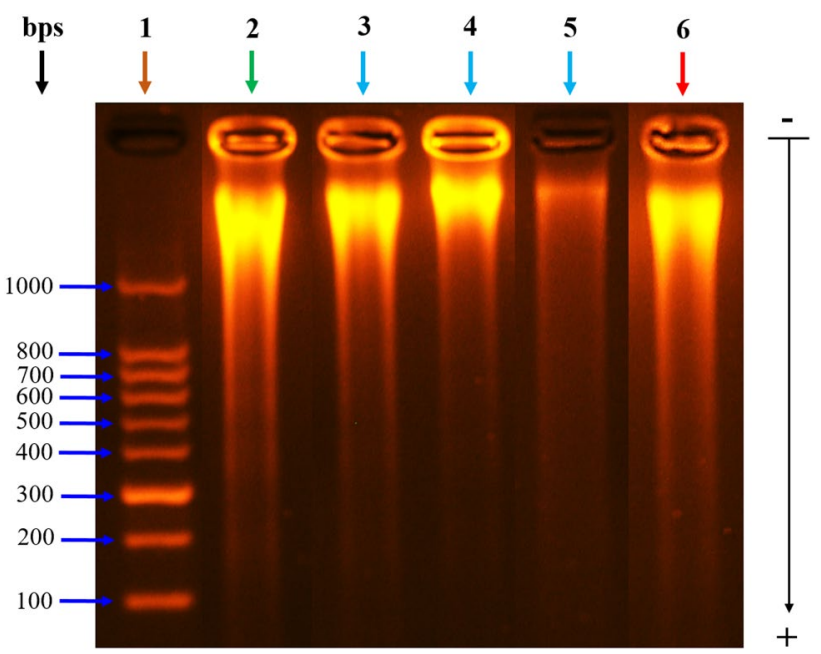

Fig. 11 Agarose gel electrophoresis mobility of: Lane 1, Marker (circular DNA), lane 2, untreated CT-DNA (4.23 mM), lanes 3-5, $4.23 \mathrm{mM}$ CT-DNA + $(0.12,0.17$ and $0.46 \mathrm{mM})$ of $[\mathrm{Pd}(\mathrm{bpy})$ (prolidtc) $\mathrm{NO}_{3}$ complex and lane $6,4.23 \mathrm{mM}$ CT-DNA $+0.12 \mathrm{mM}$ of cisplatin
Table 4 The obtained energy transfer parameters in the BSAPd(II) complex system

\begin{tabular}{lllllll}
\hline & $\mathrm{J}\left(\mathrm{cm}^{3} \cdot \mathrm{L} \cdot \mathrm{mol}^{-1}\right)$ & $\mathrm{E}$ & $\mathrm{r}(\mathrm{nm})$ & $\mathrm{R}_{0}(\mathrm{~nm})$ & $0.5 \mathrm{R}_{0}(\mathrm{~nm})$ & $1.5 \mathrm{R}_{0}(\mathrm{~nm})$ \\
\hline $\mathrm{Pd}(\mathrm{II})$ complex-BSA system & $8.66 \times 10^{-15}$ & 0.34 & 2.76 & 2.46 & 1.23 & 3.69 \\
\hline
\end{tabular}


enhancement in the DNA solution viscosity [95]. In the other form, a kink or bend in DNA duplex may be resulted through non-classical intercalation or groove binding (minor or major) of the metal complex, which leads to reducing effective DNA length and viscosity [96]_ENREF_89. To validate the binding mode of the complex with DNA, the efficacy of EB and the complex on the DNA viscosity under identical conditions were studied simultaneously. Figure 12 illustrates the alteration in the CT-DNA viscosity in the presence of EB and synthesized complex. EB, as potential intercalator, represents a notable increment in the viscosity of solutions, while the Pd(II) complex shows the same behavior in a less extent denoting insertion of the whole molecule or a part of it between DNA base pairs. This dynamic test confirms that $\left[\mathrm{Pd}(\mathrm{bpy})(\right.$ proli-dtc) $] \mathrm{NO}_{3}$ complex could intercalate between base pairs of CT-DNA.

\section{Circular dichroism spectroscopy}

Alteration in conformational forms of protein secondary structure such as $\alpha$-helix, parallel, anti-parallel, $\beta$ - turn and random coil can be detected via this powerful and sensitive tool [97]. The CD spectra of BSA without and with the [Pd(bpy)(prolidtc) $\mathrm{NO}_{3}$ complex were recorded and exhibited in Fig. 13. This protein exhibited two clear minima near $210\left(\pi \rightarrow \pi^{*}\right.$ transition) and $220 \mathrm{~nm}\left(\mathrm{n} \rightarrow \pi^{*}\right.$ transition), appearing due to the interlinks of peptides in $\alpha$-helix [98]. The CD data were expressed in terms of MRE (mean residue ellipticity) and then the percentage of $\alpha$-helical content of BSA was calculated via combining Eqs. (18) and (19)_ENREF_89.

$M R E=\frac{\theta_{0}\left(\text { deg } \cdot \mathrm{cm}^{2} \cdot d \mathrm{~mol}^{-1}\right)}{\left[C_{p} n l \times 10\right]}$

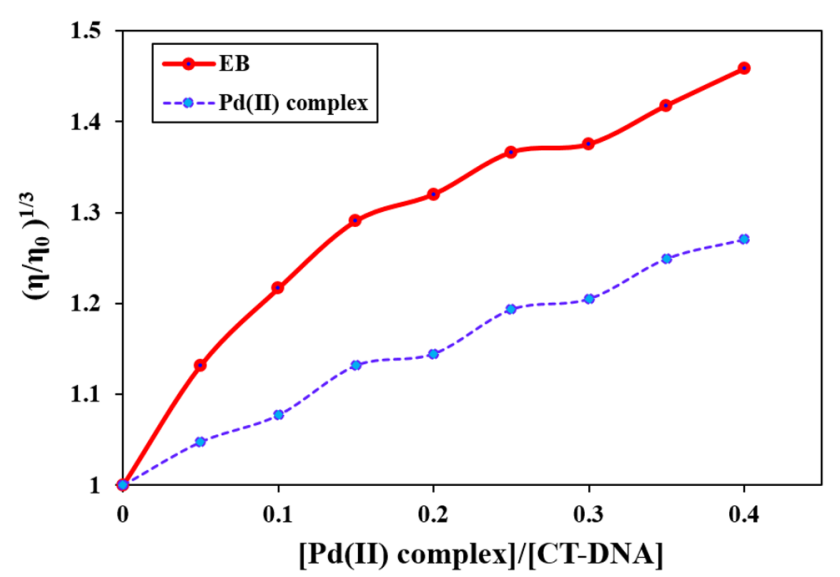

Fig. 12 Effect of various concentrations of $\left[\mathrm{Pd}(\mathrm{bpy})\right.$ (proli-dtc) $\mathrm{NO}_{3}$ complex and EB (as intercalative agent) on the relative viscosity of CT-DNA

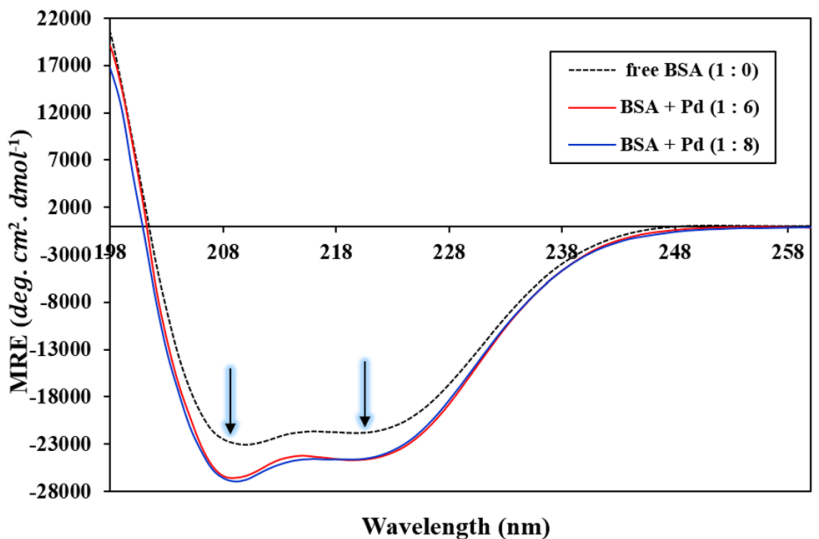

Fig. 13 Far-UV-CD spectra of BSA $(5.5 \mu \mathrm{M})$ in the absence and presence of $\left[\mathrm{Pd}(\mathrm{bpy})(\right.$ proli-dtc) $] \mathrm{NO}_{3}$ complex at $298 \mathrm{~K}$

$\alpha-\operatorname{Helix}(\%)=\left[\frac{-M R E_{210}-4000}{33000-4000}\right] \times 100$

where $\theta_{0}, l, n$ and $C p$ correspond to the value of observed $\mathrm{CD}$, the cell path length $(0.1 \mathrm{~cm})$, the number of total residues of amino acid in BSA (583), and the molar concentration of this protein, respectively. $M R E_{210}$ corresponds to the obtained MRE value at $210 \mathrm{~nm}, 4000$ indicates the MRE value of the random coil and $\beta$-form conformation at $210 \mathrm{~nm}$, and 33,000 denotes the MRE value of pure $\alpha$-helix at the same wavelength $(210 \mathrm{~nm})$. The values of elements associated with CD spectra, $\alpha$-helix, $\beta$ - turn, parallel, antiparallel and random coil, are listed in Table 5. From the obtained data, the percentage of BSA helicity is from $75.5 \%$ in free BSA to $83.1 \%$ at a molar ratio of BSA:Pd(II) complex of $1: 6$ and to $83.6 \%$ at $1: 8$, which demonstrated that interaction of $\left[\mathrm{Pd}(\mathrm{bpy})(\right.$ proli-dtc) $] \mathrm{NO}_{3}$ with $\mathrm{BSA}$ might induce some conformational alterations. Moreover, in all $\mathrm{CD}$ spectra, the shape of peaks and the peak positions were remained almost constant. These results represented that the BSA structure possesses $\alpha$-helix even after binding to the complex and does not exhibit any noticeable alteration in the CD measurements (Fig. 13).

Table 5 Analysis of percentage of $\alpha$-helix, parallel, anti-parallel, B-turn and random coil of BSA in the absence and presence of $\left[\mathrm{Pd}(\mathrm{bpy})(\right.$ proli-dtc) $] \mathrm{NO}_{3}$ complex utilizing $\mathrm{CDNN}$ program package

\begin{tabular}{llllll}
\hline & $\alpha$-Helix & Parallel & $\begin{array}{l}\text { Anti-par- } \\
\text { allel }\end{array}$ & Beta-turn & Rndm. coil \\
\hline $\begin{array}{c}\text { Free BSA } \\
\quad(1: 0)\end{array}$ & $75.50 \%$ & $2.30 \%$ & $2.40 \%$ & $9.60 \%$ & $10.20 \%$ \\
$\begin{array}{l}\text { BSA+Pd } \\
\quad(1: 6)\end{array}$ & $83.10 \%$ & $1.60 \%$ & $1.80 \%$ & $7.25 \%$ & $6.25 \%$ \\
$\begin{array}{l}\text { BSA+Pd } \\
(1: 8)\end{array}$ & $83.60 \%$ & $1.60 \%$ & $1.80 \%$ & $7.15 \%$ & $5.85 \%$ \\
\hline
\end{tabular}


Both CD and UV-Vis (Sect. 3.5.1) experiments demonstrated the same results, i.e. BSA contraction in presence of $\left[\mathrm{Pd}(\mathrm{bpy})(\right.$ proli-dtc) $] \mathrm{NO}_{3}$ solutions. According to $\mathrm{CD}$ data, the percentage of $\beta$-turn and random coil (which are roughly the extended fraction of BSA) decrease while the $\alpha$-helix (compact fraction) rises, which are the result of BSA contraction in the presence of metal complex. However, according to UV-Vis studies, the addition of Pd(II) complex to BSA solution results in a reduction in the maximum absorption at $280 \mathrm{~nm}$ showing the hiding of absorbing groups of protein from UV-light that may be due to BSA contraction. In conclusion, both of the above techniques show refolding of BSA conformation in the presence of [Pd(bpy)(proli-dtc)] $\mathrm{NO}_{3}$.

\section{Docking simulation}

Docking simulation with DNA In-silico molecular docking has been conducted to clarify the most possible binding site of DNA for metal complex interaction and evaluate their binding affinity. The most stable pose (with lowest $\Delta \mathrm{G}^{\circ}$ value) of the complex on DNA duplex demonstrated that it is located in the intercalation site of DNA through hydrophobic interaction (Fig. 14a). In [Pd(bpy)(proli-dtc) $] \mathrm{NO}_{3}$ complex, the planar rings of the bpy ligand interact with the base pairs of Gua6, Cyt5, Cyt7 and Gua8, revealing the propensity to form intercalation mode of binding through $\pi-\pi$ interactions (Fig. 14b). The relative $\Delta \mathrm{G}^{\mathrm{o}}$ of docked geometry was determined to be $-6.75 \mathrm{kcal}$. $\mathrm{mol}^{-1}$. This value is very close to the $\mathrm{UV}-\mathrm{Vis}$ finding $\left(\Delta \mathrm{G}_{\mathrm{UV}}^{\mathrm{o}}=-6.99 \mathrm{kcal}\right.$. $\mathrm{mol}^{-1}$ ), suggesting a good correlation between docking simulation and UV-Vis spectroscopy results.

Docking simulation with BSA In order to gain a perspective into the $\mathrm{Pd}(\mathrm{II})$ complex-protein binding, the docking simulation was utilized to dock $[\mathrm{Pd}(\mathrm{bpy})($ proli-dtc) $] \mathrm{NO} 3$ into the BSA structure. The BSA protein includes 2 vital drug binding sites, Sudlow's sites I and II. As a result, two possible BSA binding sites have been examined to evaluate the binding location of the compound on BSA. Molecular modelling analysis revealed that the estimated $\Delta \mathrm{G}^{\circ}$ value of the complex at drug binding site $\mathrm{I}\left(\Delta \mathrm{G}_{\text {site I }}^{\mathrm{o}}=-5.48 \mathrm{kcal} / \mathrm{mol}\right)$ was more negative than that of site II $\left(\Delta \mathrm{G}_{\text {site II }}^{\mathrm{o}}=-5.06 \mathrm{kcal} /\right.$ $\mathrm{mol}$ ), indicating this compound mainly is situated in BSA drug binding site I (Fig. 15a). Thus, we concentrated on drug binding site I for further analysis of the docking outcome. The $\Delta \mathrm{G}_{\mathrm{UV}-\mathrm{V} \text { is }}^{\mathrm{o}}$ value $(-5.18 \mathrm{kcal} / \mathrm{mol})$ is slightly different from the obtained $\Delta \mathrm{G}_{\text {docking }}^{\mathrm{o}}$ value $(-5.48 \mathrm{kcal} /$ mol). This difference is attributable to the reality that the docking protocol was conducted in the gas phase and the solvent (water) and buffer effects have been neglected [99] but UV-Vis experiment was carried out under physiological conditions. The distance between Pd(II) complex and Trp134 was estimated to be about $2.13 \mathrm{~nm}$, supporting the previous findings obtained from FRET calculation. Docking analysis shows that Pd(II) complex binds to Leu103, Ser104, Lys106, Tyr147, Ile202, Lys204, Lys242, and His246 residues via van der Waals force and forms two hydrogen bonds with Gln203 and Cys245 residues (Fig. 15b).
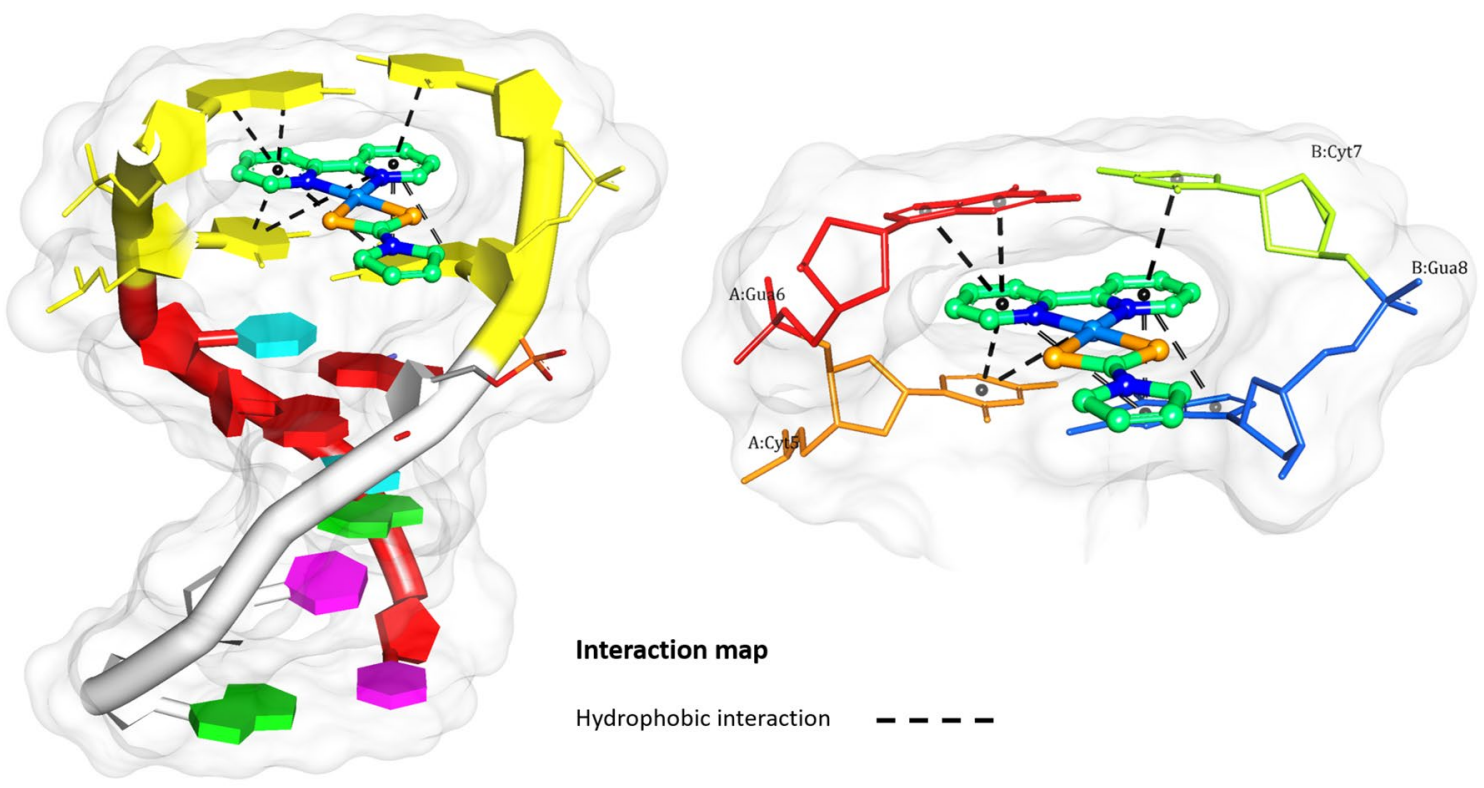

(a)

(b)

Fig. 14 Molecular docking simulation of $\left[\mathrm{Pd}(\mathrm{bpy})(\right.$ proli-dtc) $] \mathrm{NO}_{3}$ complex with DNA showing intercalation binding (a and b) 


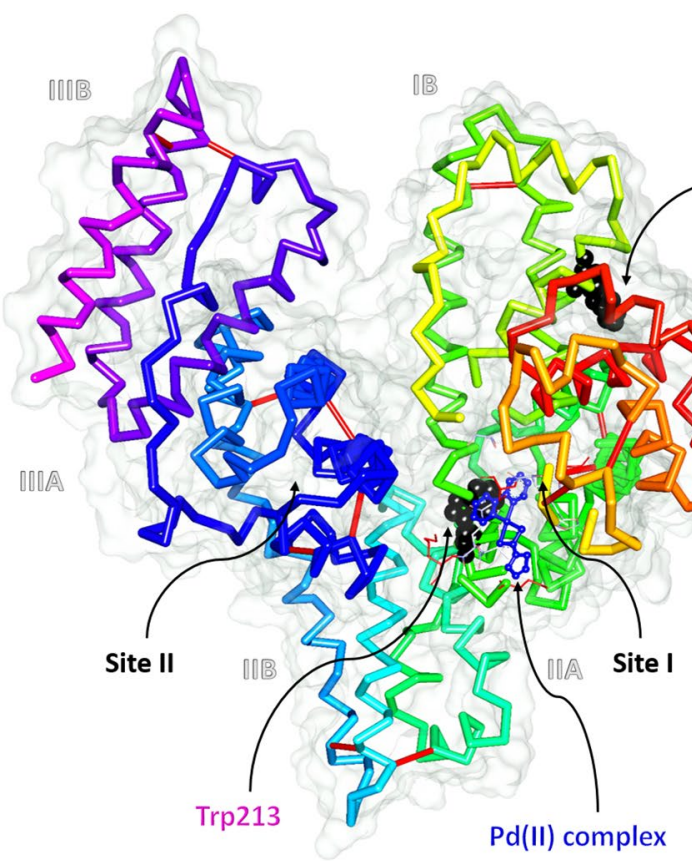

(a)

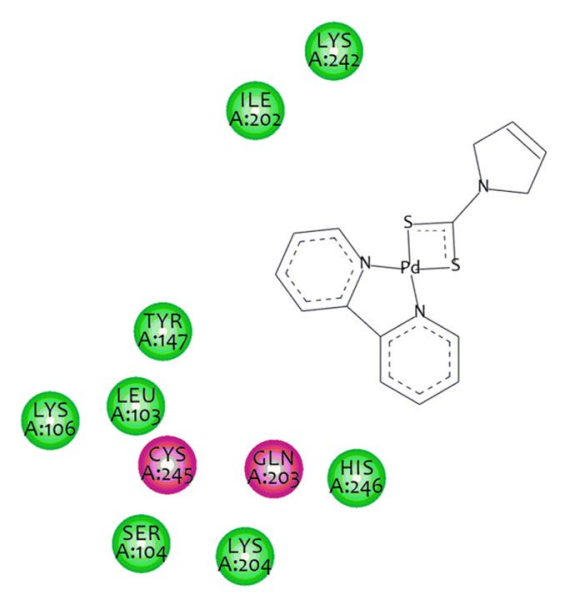

Residues interaction

Hydrogen bonding

Van der Waals interaction

(b)

Fig. 15 Molecular docking simulation of $\left[\mathrm{Pd}(\mathrm{bpy})(\right.$ proli-dtc) $] \mathrm{NO}_{3}$ complex with BSA illustrating binding site (a) as well as amino acid residues involved in the interaction (b)

The theoretical and experimental analysis mutually support each other due to (i) the type of interactions involved in DNA and BSA binding systems are consistent with fluorescence findings and, (ii) the $\Delta \mathrm{G}^{\mathrm{o}}$ values of docking study are very similar to the UV-Vis and fluorescence findings.

\section{Conclusion}

A new antiproliferative complex based on Pd(II) metal ion was synthesized and fully characterized through a variety of physicochemical methods. These procedures as well as computational details confirmed that Pd(II) complex possesses a square-planar geometry. Cytotoxic activity and lipophilicity evaluation of the new compound were also investigated and the findings were compared to that of cisplatin. Also, the interaction of the title compound with CT-DNA and BSA was studied via various methods. The obtained thermodynamic parameters $\left(\Delta \mathrm{H}^{\circ}\right.$ and $\left.\Delta \mathrm{S}^{\circ}\right)$ from fluorescence data revealed that the hydrophobic interaction and hydrogen bonds along with van der Waals forces play a crucial role in the interaction of the complex with CT-DNA and BSA, respectively. $\mathrm{UV}-\mathrm{Vis}$ and $\mathrm{CD}$ measurements suggested that the complex could lead to conformational changes in the biomolecules' native structure. The biomolecules interaction of palladium(II) complex were further confirmed via electrophoresis assay, viscosity measurement and FRET calculation. All the findings demonstrate that this complex interacts to CT-DNA (via intercalation) more strongly than BSA. Furthermore, docking simulation provides the binding site of $\left[\mathrm{Pd}(\mathrm{bpy})(\right.$ proli-dtc) $] \mathrm{NO}_{3}$ on DNA and BSA with $\Delta \mathrm{G}^{\circ}$ values of -6.75 and $-5.48 \mathrm{kcal} / \mathrm{mol}$, respectively. The experimental and computational findings illustrate that the new metal complex may be a promising agent for the cancer therapy and needs supplementary in-vivo experiments.

Supplementary Information The online version contains supplementary material available at https://doi.org/10.1007/s13738-022-02519-6.

Acknowledgements The authors acknowledge the University of Sistan and Baluchestan for the financial support.

Author contributions MF-D: Ph.D. student, ED: Guide, HM-T: Co-Guide.

Funding Not applicable.

\section{Declarations}

Conflict of interest The authors declare that they have no conflicts of interest.

\section{References}

1. J.R. Benson, I. Jatoi, M. Keisch, F.J. Esteva, A. Makris, V.C. Jordan, Lancet 373, 1463 (2009)

2. K. S. Lovejoy, S. J. Lippard, Dalton Trans. (2009) 10651. 
3. Y. Kasherman, S. Sturup, D. Gibson, J. Med. Chem. 52, 4319 (2009)

4. E.-J. Gao, K.-H. Wang, X.-F. Gu, Y. Yu, Y.-G. Sun, W.-Z. Zhang, H.-X. Yin, Q. Wu, M.-C. Zhu, X.-M. Yan, J. Inorg. Biochem. 101, 1404 (2007)

5. M. P. Hacker, E. B. Douple, I. H. Krakoff, Platinum coordination complexes in cancer chemotherapy: Proceedings of the Fourth International Symposium on Platinum Coordination Complexes in Cancer Chemotherapy Convened in Burlington, Vermont by the Vermont Regional Cancer Center and the Norris Cotton Cancer Center, June 22-24, 1983, Springer Science \& Business Media2012.

6. H.A. Ewais, M. Taha, H.N. Salm, J Chem. Eng. Data 55, 754 (2010)

7. E. Budzisz, M. Małecka, I.-P. Lorenz, P. Mayer, R.A. Kwiecień, P. Paneth, U. Krajewska, M. Rózalski, Inorg. Chem. 45, 9688 (2006)

8. E. Gao, M. Zhu, L. Liu, Y. Huang, L. Wang, C. Shi, W. Zhang, Y. Sun, Inorg. Chem. 49, 3261 (2010)

9. L. Tokareva, A. Kotova, G. Gal'pern, T. Kosoukhova, A.Y. Lanchuk, Chem. Technol. Fuels Oils 4, 566 (1968)

10. F. Blau, Ber. Dtsch. Chem. Ges. 21, 1077 (1888)

11. T. Ito, J. Higuchi, T. Hoshi, Chem. Phys. Lett. 35, 141 (1975)

12. J. Higuchi, M. Yagi, T. Iwaki, M. Bunden, K. Tanigaki, T. Ito, Bull. Chem. Soc. Japan 53, 890 (1980)

13. L. Merritt, E. Schroeder, Acta Crystallogr. A 9, 801 (1956)

14. A. Damiani, E. Giglio, A. Ripamonti, Acta Crystallogr. A 19, 161 (1965)

15. L. Malaguarnera, M. Pilastro, R. DiMarco, C. Scifo, M. Renis, M. Mazzarino, A. Messina, Apoptosis 8, 539 (2003)

16. R. Schreck, B. Meier, D.N. Männel, W. Dröge, P.A. Baeuerle, J. Exp. Med. 175, 1181 (1992)

17. S. Orrenius, C. Nobel, D. Van den Dobbelsteen, M. Burkitt, A. Slater, Portland Press Ltd.1996.

18. K.G. Daniel, D. Chen, S. Orlu, Q.C. Cui, F.R. Miller, Q.P. Dou, Breast Cancer Res. 7, R897 (2005)

19. T.G. Appleton, J.W. Connor, J.R. Hall, P.D. Prenzler, Inorg. Chem. 28, 2030 (1989)

20. E.E. Battin, J.L. Brumaghim, Cell Biochem. Biophys. 55, 1 (2009)

21. N. Pravin, N. Raman, Inorg. Chem. Commun. 36, 45 (2013)

22. M.K. Amir, S.Z. Khan, F. Hayat, A. Hassan, I.S. Butler, Inorg. Chim. Acta 451, 31 (2016)

23. T.-F. Miao, S.-Y. Liao, L. Qian, K.-C. Zheng, L.-N. Ji, Biophys. Chem. 140, 1 (2009)

24. J.-H. Shi, D.-Q. Pan, X.-X. Wang, T.-T. Liu, M. Jiang, Q. Wang, J. Photochem. Photobiol. B: Biol. 162, 14 (2016)

25. W. Lian, Y. Liu, H. Yang, H. Ma, R. Su, X. Han, B. Zhao, L. Niu, Spectrochim. Acta Part A: Mol. Biomol. Spectrosc. 207, 307 (2019)

26. B. B. Jena, L. Satish. C. S. Mahanta, B. R. Swain, H. Sahoo, B. P. Dash, R. Satapathy, Inorganica Chimica Acta 49152 (2019) .

27. T. Tantimongcolwat, S. Prachayasittikul, V. Prachayasittikul, Spectrochim. Acta Part A: Mol. Biomol. Spectros. 216, 25 (2019)

28. K. Karami, N. Jamshidian, M. Zakariazadeh, Appl. Organomet. Chem. 33, e4728 (2019)

29. F.A. Palocsay, J.V. Rund, Inorg. Chem. 8, 524 (1969)

30. S. Shahraki, F. Shiri, H. Mansouri-Torshizi, J. Shahraki, J. Iran. Chem. Soc. 13, 723 (2016)

31. D. Menezes, F. Vieira, G. de Lima, A. Porto, M. Cortés, J. Ardisson, T. Albrecht-Schmitt, Eur. J. Med. Chem. 40, 1277 (2005)

32. A. Manohar, K. Ramalingam, G. Bocelli, L. Righi, Inorg. Chim. Acta 314, 177 (2001)

33. K. Nakamoto, John Wiley \& Sons, New York (1986).

34. T. H. MANSOURI, S. M. AKHBARI, T. Srivastava, (2001).

35. T. Diao, P. White, I. Guzei, S.S. Stahl, Inorg. Chem. 51, 11898 (2012)
36. M. Feizi-Dehnayebi, E. Dehghanian, H. Mansouri-Torshizi, Spectrochim. Acta Part A: Mol. Biomol. Spectrosc. 249, 119215 (2021)

37. M. Frisch, F. Clemente, Scalmani, V. Barone, B. Mennucci, GA Petersson, H. Nakatsuji, M. Caricato, X. Li, HP Hratchian, AF Izmaylov, J. Bloino, G. Zhe.

38. C. Lee, W. Yang, R.G. Parr, Phys. Rev. B 37, 785 (1988)

39. R.G. Mohamed, F.M. Elantabli, A.A.A. Aziz, H. Moustafa, S.M. El-Medani, J. Mol. Struct. 1176, 501 (2019)

40. S. Jagadeesan, V. Balasubramanian, P. Baumann, M. Neuburger, D. Häussinger, C.G. Palivan, Inorganic Chem. 52, 12535 (2013)

41. M. Islami-Moghaddam, H. Mansouri-Torshizi, A. Divsalar, A. Saboury, J. Iran. Chem. Soc. 6, 552 (2009)

42. A. Divsalar, M. Razmi, A.A. Saboury, H. Mansouri-Torshizi, F. Ahmad, Cell Biochem. Biophy. 71, 1415 (2015)

43. J. Zhang, L. Li, L. Wang, F. Zhang, X. Li, Eur. J. Med. Chem. 45, $5337(2010)$

44. A. Heydari, H. Mansouri-Torshizi, RSC Adv. 6, 96121 (2016)

45. M. A. Teir, J. GHITHAN. S. DARWISH, M. M. ABU-HADID, J. Appl. Biol. Sci. 6, 45 (2012).

46. J. Olmsted III., D.R. Kearns, Biochemistry 16, 3647 (1977)

47. J.-H. He, D.-R. Xiao, H.-Y, Chen, D.-Z. Sun, S.-W. Yan, X. Wang, Z.-L. Ye, Q.-L, Luo, E.-B. Wang, J. Solid State Chem. 198, 279 (2013).

48. G. Böhm, R. Muhr, R. Jaenicke, Protein Engineering. Design Sel. 5, 191 (1992)

49. V. Gauss View, Semichem Inc (2009).

50. M. Feizi-Dehnayebi, E. Dehghanian, H. Mansouri-Torshizi, J. Mol. Struct. 1240, 130535 (2021)

51. C. Makedonas, C. A. Mitsopoulou, F. J. Lahoz, A. I. Balana, Inorganic Chem. 42, 8853 (2003).

52. P. Politzer, J. S. Murray, Z. Peralta-Inga, Int. J. Quantum Chem. 85 (2001) 676.

53. H. Gökce, S. Bahçeli, Spectrochim. Acta Part A Mol. Biomol. Spectrosc. 114, 61 (2013)

54. M. Theetharappan. L. Subha. C. Balakrishnan, M. Neelakantan, Applied Organometallic Chemistry 31 (2017) e3713.

55. N. El-Ghamaz, M. Diab, A. El-Bindary, A. El-Sonbati, H. Seyam, Mater. Sci. Semicond. Process. 27, 521 (2014)

56. B. Shekhar, P. Vasantha, B. Sathish Kumar, P. Anantha Lakshmi, V. Ravi Kumar, S. Satyanarayana, Appl. Organomet. Chem., 33, e5086 (2019).

57. S. Shahraki, A. Heidari, H. Mirzaei, M. Saeidifar, N. Ahmadinasab, H. Mansouri-Torshizi, J. Iran. Chem. Soc. 15, 697 (2018)

58. R.G. Parr, R.G. Pearson, J. Am. Chem. Soc. 105, 7512 (1983)

59. R.G. Pearson, J. Org. Chem. 54, 1423 (1989)

60. R. Kavitha, S. Nirmala, R. Nithyabalaji, R. Sribalan, J. Mol. Struct. 1204, 127508 (2020)

61. C.A. Puckett, J.K. Barton, J. Am. Chem. Soc. 129, 46 (2007)

62. Y. Yang, O. Engkvist, A. Llinàs, H. Chen, J. Med. Chem. 55, 3667 (2012)

63. Z. Liu, A. Habtemariam, A. M. Pizarro, S. A. Fletcher, A. Kisova, O. Vrana. L, Salassa, P. C. Bruijnincx, G. J. Clarkson, V. Brabec, J. Med. Chem., 54, 3011 (2011).

64. A. Kumar, A. Kumar, R.K. Gupta, R.P. Paitandi, K.B. Singh, S.K. Trigun, M.S. Hundal, D.S. Pandey, J. Organomet. Chem. 801, 68 (2016)

65. H. Huang, P. Zhang, H. Chen, L. Ji, H. Chao, Chem. Eur. J. 21, $715(2015)$

66. V.T. Yilmaz, C. Icsel, O.R. Turgut, M. Aygun, M. Erkisa, M.H. Turkdemir, E. Ulukaya, Eur. J. Med. Chem. 155, 609 (2018)

67. P. Sathyadevi, P. Krishnamoorthy, E. Jayanthi, R.R. Butorac, A.H. Cowley, N. Dharmaraj, Inorg. Chim. Acta 384, 83 (2012)

68. A. Pyle, J. Rehmann, R. Meshoyrer, C. Kumar, N. Turro, J.K. Barton, J. Am. Chem. Soc. 111, 3051 (1989) 
69. A. A. Recio Despaigne, J. G. Da Silva, P. R. Da Costa, R. G. Dos Santos, H. Beraldo, Molecules, 19, 17202 (2014).

70. H. Yin, H. Liu, M. Hong, J. Organomet. Chem. 713, 11 (2012)

71. Y.-B. Zeng, N. Yang, W.-S. Liu, N. Tang, J. Inorg. Biochem. 97, $258(2003)$

72. B. Yue, H.J. Sun, Y.N. Chen, K. Kong, H.B. Chu, Y.L. Zhao, Appl. Organomet. Chem. 28, 162 (2014)

73. A. Sułkowska, J. Mol. Struct. 614, 227 (2002)

74. M. Kumar, D.T. Masram, Polyhedron 157, 511 (2019)

75. J. R. Lakowicz, Principles of fluorescence spectroscopy, Springer science \& business media2013.

76. R. Prabu. A. Vijayaraj. R. Suresh. R. Shenbhagaraman. V. Kaviyarasan, V. Narayanan, Journal of the Iranian Chemical Society 11 (2014) 825.

77. N. Gan. Q. Sun. P. Tang. D. Wu. T. Xie. Y. Zhang, H. Li, Spectrochimica Acta Part A: Molecular and Biomolecular Spectroscopy 206 (2019) 126.

78. A.T. Buddanavar, S.T. Nandibewoor, Journal of pharmaceutical analysis 7, 148 (2017)

79. Y.-J. Hu. Y. Liu. L.-X. Zhang. R.-M. Zhao, S.-S. Qu, Journal of Molecular Structure 750 (2005) 174.

80. W.R. Ware, J. Phys. Chem. 66, 455 (1962)

81. M. Saeidifar. R. Sabbaghzadeh, N. A. Nasab, Polycyclic Aromatic Compounds (2020) 1.

82. K.L. Zhou, D.Q. Pan, Y.Y. Lou, J.H. Shi, J. Mol. Recognit. 31, e2716 (2018)

83. O.A. Chaves, V.A. da Silva, C.M.R. Sant'Anna, A.B. Ferreira, T.A.N. Ribeiro, M.G. de Carvalho, D. Cesarin-Sobrinho, J.C. Netto-Ferreira, J. Mol. Struct. 1128, 606 (2017)

84. Z. Shams, A. Divsalar, B. Ghalandari, F. Sanginabadi, A. Saboury, H. Mansouri-Torshizi, J. Iran. Chem. Soc. 18, 873 (2021)
85. J.-h, Shi, D.-q. Pan, M. Jiang, T.-T. Liu, Q. Wang, J Photochem Photobiol B: Biol 164, 103 (2016).

86. P.D. Ross, S. Subramanian, Biochemistry 20, 3096 (1981)

87. I.M. Klotz, Ann. N. Y. Acad. Sci. 226, 18 (1973)

88. M. Anjomshoa, S.J. Fatemi, M. Torkzadeh-Mahani, H. Hadadzadeh, Spectrochim. Acta Part A: Mol. Biomol. Spectros. 127, 511 (2014)

89. M. Feizi-Dehnayebi, E. Dehghanian, H. Mansouri-Torshizi, J. Mol. Liq. 344, 117853 (2021)

90. S. Jana, S. Dalapati, S. Ghosh, N. Guchhait, J. Photochem. Photobiol. A: Chem. 231, 19 (2012)

91. S. Shahraki, F. Shiri, M.H. Majd, S. Dahmardeh, J. Iran. Chem. Soc. 16, 301 (2019)

92. D. Li, M. Zhu, C. Xu, B. Ji, Eur J. Med. Chem. 46, 588 (2011)

93. J.-Y. Yang, W.Y. Yang, J. Am. Chem. Soc. 131, 11644 (2009)

94. V.D. Suryawanshi, L.S. Walekar, A.H. Gore, P.V. Anbhule, G.B. Kolekar, J. Pharm. Anal. 6, 56 (2016)

95. Z. Asadi, N. Nasrollahi, M. Golchin, J. Iran. Chem. Soc. 16, 2479 (2019)

96. M. Bordbar, M. Tabatabaee, M. Alizadeh-Nouqi, Z. Mehri-Lighvan, H.R. Khavasi, A. YeganehFaal, F. Fallahian, M. Dolati, J. Iran. Chem. Soc. 13, 1125 (2016)

97. F. Fathi, M. Sharifi, A. Jafari, N. Kakavandi, S. Kashanian, J.E.N. Dolatabadi, M.-R. Rashidi, J. Mol. Liq. 296, 111770 (2019)

98. B. Chakraborty, C. Sengupta, U. Pal, S. Basu, J. Chem. 41, 12520 (2017)

99. M. Shaghaghi, S. Rashtbari, S. Vejdani, G. Dehghan, A. Jouyban, R. Yekta, Luminescence 35, 512 (2020) 